\title{
PRIVATE EQUITY FONDOVI I HRVATSKO ISKUSTVO
}

\author{
Dr. sc. Morana Derenčinović Ruk*
}

UDK: $336.714(497.5)$

347.721:336.714(497.5)

DOI: 10.3935/zpfz.70.6.03

Pregledni znanstveni rad

Primljeno: prosinac 2020.

U radu se analiziraju private equity fondovi i njihove posebnosti te se prikazuju hrvatska iskustva u tom području. Daje se određenje pojmova private equity $i$ private equity fondovi, nakon čega se pojašnjavaju osnovne karakteristike private equity fondova, koje utječu na način njihova rada. Također se prikazuju strukture private equity fondova u svijetu, formirane ponajprije zbog poreznih $i$ pravnih razloga. Nadalje se iznose razlike u odnosu na Hrvatsku te pravne prepreke koje hrvatski zakonodavni okvir postavlja efikasnom i efektivnom funkcioniranju private equity fondova te prijedlozi de lege ferenda. Na kraju se prikazuje hrvatsko iskustvo, sopisom prvih takvih fondova u Hrvatskoj i posebnim osvrtom na fondove za gospodarsku suradnju kao posebnost hrvatskog tržišta kapitala $i$ private equity industrije.

Ključne riječi: private equity, alternativni investicijski fond, fond za gospodarsku suradnju, strategija

* Dr. sc. Morana Derenčinović Ruk, Hrvatska agencija za nadzor financijskih usluga (HANFA), Franje Račkoga 6, 10000 Zagreb; mderencinovic@gmail.com, morana. derencinovic@hanfa.hr;

ORCID ID: orcid.org/0000-0002-6624-7896 


\section{UVOD**}

Private equity fondovi važni su igrači na tržištu kapitala, koji na svjetskoj i europskoj razini u ciljna društva svake godine ulažu milijarde dolara i eura, unaprjeđujući tako poslovanje i razvoj ciljnih društava u gotovo svim fazama njihova razvoja. Premda Hrvatska u tom pogledu uvelike zaostaje - kako u dijelu da strani private equity fondovi ulažu u hrvatska ciljna društva, tako i $\mathrm{u}$ dijelu razvoja private equity industrije u Hrvatskoj - smatramo da je važno analizirati private equity fondove i njihove posebnosti baš kako bi se iz domene nečeg nepoznatog i donekle eteričnog došlo do stvarnog stanja stvari i njihova razumijevanja.

Stoga će se u radu nastojati dati određenje private equity fondova, koje je neraskidivo povezano s pojmom private equity te osnovne karakteristike private equity fondova koje su važne za razumijevanje načina njihova rada, odnosa prema ciljnom društvu i ulagateljima. Naime, private equity fondovi imaju određeno trajanje i specifičan životni ciklus podijeljen u etape, vrlo su rizični (rizičniji i od "zloglasnih" hedge fondova) i u njih ulažu profesionalni ulagatelji, a upravitelji fonda izuzetno su aktivni i angažirani u ciljnim društvima. Prikazuju se i strukture private equity fondova koje su u svijetu dominantne, a riječ je o (private) limited partnershipu koji nije pravna osoba i omogućuje neograničenu odgovornost upravitelja i ograničenu odgovornost ulagatelja, dok onemogućuje oporezivanje na razini private equity fonda. Takve strukture u Hrvatskoj ne postoje, a najviše odgovaraju komanditnom društvu, no ono za sada nije dopušten oblik ustrojavanja private equity ili bilo kojeg drugog alternativnog investicijskog fonda, zbog čega se daju konkretni de lege ferenda prijedlozi za unaprjeđenje zakonodavnog okvira poslovanja private equity fondova.

Za potrebe rada provjeravani su javno dostupni podaci o konkretnim ulaganjima društava za upravljanje private equity fondovima, koji su zatim uspoređivani s onima iz sudskoga registra, Središnjeg klirinškog depozitarnog društva d.d. i Zagrebačke burze d.d. Također su analizirani podaci iz statističkih izvještaja Hanfe. Osim navedenoga, putem posebno kreiranog upitnika od hrvatskih društava za upravljanje private equity fondovima zatraženi su određeni podaci

** Autorica je zaposlena u Hrvatskoj agenciji za nadzor financijskih usluga kao direktorica Sektora za superviziju fondova i investicijskih društava. Stavovi i mišljenja autorice izneseni u ovom članku osobni su stavovi i ne odražavaju stavove Hrvatske agencije za nadzor financijskih usluga. Autorica zahvaljuje Marku, koji joj je otkrio brojne tajne private equityja i naučio je toliko toga, i dragom prijatelju D. na pomoći, savjetima, iskustvu i komentarima. Zahvala i svim društvima za upravljanje private equity fondovima u Hrvatskoj koja su pomogla u istraživanju i pribavljanju podataka. Bez njihove suradnje kvalitetan prikaz stanja u Hrvatskoj ne bi bio moguć. 
kako bi se stekao uvid u način njihova rada i stanje na hrvatskom private equity tržištu te su odgovori društava sublimirani u zaključcima stanja hrvatskog private equity tržišta.

\section{ODREĐENJE, OSNOVNE KARAKTERISTIKE I STRUKTURE PRIVATE EQUITY FONDOVA}

\subsection{Određenje pojma private equity}

Private equity fondovi (dalje u tekstu: PE fondovi) pripadaju kategoriji alternativnih investicijskih fondova i na tržištu kapitala posljednjih godina imaju sve veću ulogu kao alternativni izvori financiranja, posebice za mala i srednja poduzeća (tzv. SME - small and medium enterprises). Ne postoji općeprihvaćena i dogovorena definicija PE fondova i nije ju lako dati. Kako bi se razumio način i logika rada PE fondova, u nastavku ćemo nastojati ponuditi određenje pojma private equity kao vrste ulaganja, kako bi se zatim odredili PE fondovi. Riječ je o engleskim izrazima koji su ustaljeni i prihvaćeni u teoriji i praksi, a nije ih lako prenijeti u hrvatsko govorno područje.

Private equity je vrsta ulaganja u kapital subjekta koja podrazumijeva stjecanje, i to u pravilu kupnju, udjela u subjektima putem privatno organiziranih transakcija. ${ }^{1}$ Tu su bitne dvije odrednice:

1. Riječ je o ulaganju u kapital subjekta koji je najčešće trgovačko društvo, i to društvo s ograničenom odgovornošću (d. o. o.) ili dioničko društvo (d. d.), što znači da se stječu udjeli ili dionice u tomu društvu. Zbog toga će se u radu i koristiti izrazi ulaganje u društvo, stjecanje društva, ciljno društvo i sl.

2. Ulaže se $u$ pravilu $u$ društva dionice kojih nisu uvrštene na uređenom tržištu ili burzi radi trgovanja (tzv. privatna društva, odakle i private $\mathrm{u}$ samome nazivu), zbog čega podaci o takvim ulaganjima nisu javno dostupni (nema obveze njihova objavljivanja s aspekta transparentnosti, kao što je to slučaj s listanim društvima).

1 Vidi primjerice Šimić, M., Atraktivnost Hrvatske u privlačenju ulagača rizičnog kapitala, Ekonomska misao i praksa, br. 1, 2015., str. 270 - 272, gdje se daje pregled različitih definicija private equityja, posebice od strane private equity i venture capital asocijacija. Nadalje vidi određenje private equityja na https://www.investopedia.com/ terms/p/privateequity.asp i https://www.blackrock.com/us/individual/education/ what-are-alternative-investments/private-equity-investing te brojne druge. (19. travnja 2020.). 


\subsection{Određenje pojma PE fonda i njegovih osnovnih karakteristika}

PE fondove najjednostavnije možemo odrediti kao alternativne investicijske fondove investicijska strategija kojih je ulaganje imovine u udjele, dionice i obveznice trgovačkih društava koja nisu listana na uređenom tržištu ili burzi. ${ }^{2}$ I tu izdvajamo nekoliko ključnih odrednica:

1. Riječ je o alternativnim investicijskim fondovima (dalje u tekstu: AIF) kod kojih propisi, u pravilu, ne određuju dozvoljena ulaganja i/ili njihova ograničenja - odabir ulaganja i načina ulaganja je na društvu za upravljanje fondom koje upravo izborom investicijske strategije PE fonda (koja se proklamira u osnovnim dokumentima fonda - pravila) određuje način rada fonda u svim etapama njegova životnog ciklusa. ${ }^{3}$

2 U odnosu na nepostojanje jedinstvene definicije PE fondova i različita određenja vidi Čulinović-Herc, E.; Braut Filipović, M.; Audić Vuletić, S., Novo pravno uređenje private equity $i$ venture capital fondova i otvorena pitanja, Zbornik Pravnog fakulteta Sveučilišta u Rijeci, vol. 38, br. 1, 2017., str. 51 - 92, koje ujedno daje i aktualan prikaz zakonodavnog okvira private equity fondova; Wymeersch, E., The regulation of private equity, hedge funds and state funds, Financial Law Institute, Working Paper Series WP, 2010-06, str. 24; European Commission Internal Market and Services DG, Report of the Alternative Investment Expert Group Developing European Private Equity, July 2006., str. 9; Debevoise \& Plimpton, Private Equity Funds, Key Business, Legal and Tax Issues, 2015., str. 3; Pantheon, Understanding private equity and private equity funds, str. 6.

3 Za razliku od alternativnih investicijskih fondova, kod UCITS fondova propisi točno određuju u što se imovina fonda može ulagati, kako i s kojim ograničenjima te ulagatelji imaju pravo svakodobno otkupiti udjele $u$ takvim fondovima (zbog toga je u svijetu poznat tzv. UCITS label). AIF-ovi su u Hrvatskoj uređeni Zakonom o alternativnim investicijskim fondovima (Narodne novine, br. 21/2018 i 126/2019; dalje u tekstu: ZAIF) i definirani kao investicijski fondovi osnovani sa svrhom i namjenom: a) prikupljanja sredstava javnom ili privatnom ponudom od ulagatelja te ulaganja tih sredstava u skladu s unaprijed određenom strategijom i ciljem ulaganja AIF-a, a isključivo u korist imatelja udjela tog AIF-a te koji b) ne zahtijeva odobrenje za osnivanje i upravljanje UCITS fondom u skladu s odredbama zakona kojim se uređuje osnivanje i rad otvorenih investicijskih fondova s javnom ponudom. Definicija AIF-a je, dakle, jednim dijelom negativna - jer svaki fond koji nije UCITS fond jest AIF - vidi čl. 4. t. 3. ZAIF-a i čl. 4. t. 1. (a) Direktive 2011/61/ EU Europskog Parlamenta i Vijeća od 8. lipnja 2011. o upraviteljima alternativnih investicijskih fondova i o izmjeni direktiva 2003/41/EZ i 2009/65/EZ te uredbi (EZ) br. 1060/2009 i (EU) br. 1095/2010 (tzv. AIFM Direktiva), koja je u hrvatsko zakonodavstvo prenesena kroz "stari" Zakon o alternativnim investicijskim fondovima (Narodne novine, br. 16/2013 i 143/2014). AIFM Direktiva inače ne uređuje AIF-ove, nego upravitelje AIF-ova te je Hrvatska jedna od rijetkih zemalja koja je zakonom uredila i upravitelje AIF-ova i same AIF-ove. UCITS fondovi u Hrvat- 
2. Imovina fonda ulaže se u udjele, dionice i obveznice trgovačkih društava, kao i druge izvedenice koje na njima počivaju (to je equity u koji se ulaže).

3. Imovina fonda ulaže se u prvom redu u privatna društva i upravo to je ključno za uspjeh samoga ulaganja. ${ }^{4}$

Narav PE fondova, rizici ulaganja i način njihova rada rezultirali su određenim karakteristikama PE fondova, koje u nastavku navodimo. Pritom napominjemo da su te karakteristike ponajprije stvar fakticiteta i prakse, a ne regulative:

1. Ulagatelji u PE fond su u prvom redu profesionalni ulagatelji, tj. institucionalni ulagatelji - prema pravnom okviru ulagatelji u PE fondove (kao i u druge AIF-ove) mogu biti i mali ulagatelji, no AIF-ovi općenito nisu namijenjeni malim ulagateljima. ${ }^{5}$ Zbog toga su u praksi ulagatelji u PE fondove ponajprije profesionalni ulagatelji, tj. institucionalni ulagatelji - mirovinski i

skoj su uređeni Zakonom o otvorenim investicijskim fondovima s javnom ponudom (Narodne novine, br. 44/2016 i 126/2019).

Postoje različite strategije ulaganja i investicijske tehnike PE fondova, koje određuju poslovne i pravne aspekte poslovanja PE fonda. Osnovne strategije ulaganja private equity fondova jesu: Leveraged Buyout (LBO), Management Buyout, Venture Capital, Growth/Expansion Capital, Mezzanine, Distressed/Special Situations i preostale strategije. Područja (sektori) u koja PE fondovi ulažu različita su i ovise o izabranoj investicijskoj strategiji, pa su to primjerice uslužne djelatnosti (trgovački centri, restorani i pubovi), nekretnine, infrastruktura (brane, aerodromi), prava i patenti (primjerice filmska i muzička prava, sportska prava, lijekovi), razne vrste kladionica, proizvodnja hrane, IT, financijska industrija i sl. Neka od najpoznatijih svjetskih društava i brendova započela su ili proširila svoj rad zahvaljujući ulaganju PE fondova Apple, Cisco Systems, Compaq, Genetech, Google, Facebook, Tesla, Staples, Sun Mycrosystems, Equinox, Dell, Beat Eletronics, Skype, Facebook, Versace, Hilton, Harrods, Burger King, Dunkin' Donuts, Shake Shack, Kraft Heinz i dr.

4 Postoje i PE fondovi koji su iznimka od ovoga pravila te ulažu u društva koja jesu listana na uređenom tržištu, ali tada najčešće u dionice, udjele ili obveznice koje nisu listane, nakon čega u pravilu uvijek delistaju to društvo s uređenog tržišta (tako Čulinović-Herc; Braut Filipović; Audić Vuletić, op. cit. u bilj. 2, str. 57). Kod takvih je PE fondova često predviđena mogućnost otkupa udjela in specie - dakle, otkupa udjela prijenosom odgovarajućeg postotka imovine iz PE fonda ulagatelju, što je potrebno i korisno zbog održavanja stope rentabilnosti i/ili povrata.

5 Za razliku od UCITS fondova koji su namijenjeni malim ulagateljima, kod AIF-ova to nije slučaj - oni su namijenjeni u prvom redu profesionalnim ulagateljima (vidi određenje u čl. 101. Zakona o tržištu kapitala, Narodne novine, br. 65/2018 i 18/2020). ZAIF u čl. 4. t. 58. predviđa i posebnu kategoriju kvalificiranog ulagatelja u AIF rizičnog kapitala. ZAIF, također, predviđa posebno odobrenje Hanfe za distribuciju udjela AIF-ova malim ulagateljima - vidi čl. 151. ZAIF-a. 
investicijski fondovi, tzv. Sovereign Wealth fondovi ${ }^{6}$, društva za osiguranje, velike kompanije i bogati pojedinci. ${ }^{7}$ Osnovni razlog ulaganja u PE fondove jest diversifikacija imovine i nekorelirani povrat na ulaganje jer je riječ o fondovima koji uz veći rizik daju potencijalno veće povrate nego što bi se inače moglo ostvariti na tržištu kapitala. ${ }^{8}$ Također, ulagatelji nemaju utjecaj na upravljanje PE fondom i na njegova ulaganja (što je i logično - zato su i povjerili profesionalcima svoju imovinu na upravljanje). ${ }^{9}$

2. Određeno trajanje PE fonda-PE fondovi u pravilu imaju određeno trajanje, koje je 10 godina uz mogućnost produljenja dvije ili tri godine. U pravilu svi PE fondovi imaju tako određeno trajanje, premda realizacija određenog

$6 \quad$ Sovereign Wealth fondovi su investicijski fondovi kod kojih je imatelj udjela država ili pojedine državne institucije čija se imovina ulaže za račun te države. Posljednjih su godina takvi fondovi postali iznimno veliki ulagatelji na tržištu kapitala, pa tako i u domeni PE fondova. Zbog veličine ti fondovi često ulažu pod povoljnijim uvjetima od ostalih ulagatelja, u odnosu na naknade za upravljanje, izlazne naknade, mogućnost izlaza iz fonda, utjecaja na rad fonda (investicijska strategija) i sl. Najpoznatiji SWF je svakako Government Pension Fund of Norway, koji se u biti sastoji od dvaju investicijskih fondova (Government Pension Fund Global poznat kao i Oil Fund, i Government Pension Fund of Norway). Njegova imovina u svibnju 2020. godine iznosi 1,063.0 milijardi dolara i treći je po veličini SW fond na svijetu. Osim toga, Kina ima SW fond (China Investment Corporation, koji u svibnju 2020. godine ima 1,554.8 milijardi dolara imovine pod upravljanjem i najveći je SW fond na svijetu, a do 2022. godine planira uložiti 50 \% imovine u alternativnu imovinu), jednako kao i Ujedinjeni Arapski Emirati (Mubadala Investment Company, koji u svibnju 2020. godine ima 1,298.7 milijardi dolara imovine pod upravljanjem i drugi je najveći SW fond na svijetu), a tu je i Singapur s četvrtim po veličini SF fondom (u biti Singapur ima dva SW fonda - GIC Private Limited i Temasek) te Katar (Qatar Investment Authority). Vidi i Wymeersch, op. cit. u bilj. 2, str. 28 - 31 te Private Equity Funds, Key Business, Legal and Tax Issues, op. cit. u bilj. 2, str. 61.

7 Bogati pojedinci (tzv. high net worth investors), posebice u SAD-u, ulažu u PE fondove ili individualno ili putem tzv. family officea koji kao posebni savjetnici vode računa o njihovim ulaganjima.

8 U pravilu PE fondovi ostvaruju povrat koji je cca. 11 \% veći od tržišnog, vidi Understanding private equity and private equity funds, op. cit. u bilj. 2, str. 14.

9 Vidi Harris, L., A critical theory of private equity, Delaware Journal of Corporate Law, vol. 35, br. 1, 2020. (dostupno na: https://ssrn.com/abstract=1557360).

U Velikoj Britaniji je, primjerice, uobičajeno da je za ulaganje u PE fond potrebno minimalno pet do deset milijuna funti (kod nekih manjih fondova je dostatno i 500.000 funti.), vidi Payne, J., Private Equity and its Regulation in Europe, Oxford Legal Research Paper Studies, Paper, no. 40/2011., 7/2011. Prema podacima Invest Europe za 2018. godinu u etapi prikupljanja kapitala PE fondova kao ulagatelji su sudjelovali mirovinski fondovi (31 \%), razni investicijski fondovi (18\%), familiy offices i privatni ulagatelji (11 \%), društva za osiguranje (11 \%) i SW fondovi (9 \%). 
ulaganja uvelike ovisi o investicijskoj strategiji PE fonda, pa primjerice venture capital fondovi u kraćem razdoblju realiziraju svoja ulaganja no što je to slučaj s ostalim PE fondovima. Međutim, postoje i iznimke od toga pravila, pa kod PE fondova postoji i tzv. roll over, tj. produljenje trajanja PE fonda, uz mogućnost promjene njegove strukture ili prenošenja $u$ druge jurisdikcije (što će primarno biti uzrokovano poreznim razlozima). Također postoje i evergreen ${ }^{10}$ PE fondovi koji nemaju određeno trajanje.

3. PE fondovi imaju srednji do dugoročni horizont ulaganja (3 - 7 - 10 godina), ovisno o odabranoj strategiji.

4. Određeni životni ciklus fonda (etape) - PE fondovi imaju svoj životni ciklus, koji je opet povezan s investicijskom strategijom fonda. Ukratko ${ }^{11}$, u prvoj etapi potencijalni ulagatelji preuzimaju obvezu ulaganja u fond (čime fond stječe utuživu tražbinu prema ulagateljima) te se prikupljaju novčana sredstava. Tada se zainteresiranim ulagateljima prezentiraju okviri investicijske strategije i ulaganja PE fonda. Zatim slijedi etapa ulaganja prikupljenih sredstava, u kojoj se provodi detaljno tržišno, financijsko, pravno, okolišno i upravno dubinsko snimanje (due diligence) ciljnog društva, što može trajati i više mjeseci prije no što se formira i donese konačna odluka o ulaganju. Kada se PE fond odluči za konkretno ulaganje, ovisno o investicijskoj strategiji, PE stječe equity u ciljnom društvu, nakon čega slijedi etapa upravljanja ulaganjima u kojoj se unaprjeđuje i razvija poslovanje ciljnog društva, potencijalno mijenja veličina ciljnog društva i repozicionira njegov tržišni udio, uvode novi proizvodi i usluge i sl. Na samome kraju je izlazna etapa (dezinvestiranje, exit), kada se monetizira dio stvorene imovine, prodaje dio ili cijelo društvo.

10 Neki od najvećih upravitelja PE fondova na svijetu (Blackstone Group, Carlyle Group) imaju evergreen fondove te se ističe kako su oni u biti jako korisni jer se na taj način bolje ujednačavaju interesi upravitelja i ulagatelja, ali i interesi PE fonda i društava u koja se ulaže. Vidi https://www.institutionalinvestor.com/article/bl5jkqt382wm4r/why-critics-are-slamming-an-increasingly-popular-private-equity-format (19. travnja 2020.). Ponekad, doduše, PE fond neplanirano postane evergreen jer ne može ostvariti izlaz iz investicije ili se ne uspije likvidirati ili je neka investicija pošla po krivu i sl. Prema nekim podacima čak 20 \% PE fondova su evergreen fondovi.

Prema Derenčinović Ruk, M., Restrukturiranje društava u poteškoćama i tržište kapitala - vrste i upravljanje sukobom interesa, Zbornik Pravnog fakulteta Sveučilišta u Rijeci, vol. 39, br. 4, 2018., str. 1664 . 
5. Rizičnost - riječ je o rizičnim fondovima, a njihova rizičnost proizlazi u prvom redu iz njihovih ulaganja. ${ }^{12}$ Naime, PE fondovi ulažu u equity privatnih društva i brojna ulaganja ne uspiju iz raznih razloga - loše procjene, netransparentnosti informacija, loše suradnje s upravom ciljnog društva, lošem tržišnom ili gospodarskom trenutku (market timing) i dr. S time je povezan i rizik (ne)likvidnosti ${ }^{13}$ jer su ulaganja PE fondova u pravilu vrlo nelikvidna s obzirom na njihov objekt - udjele/dionice u privatnim društvima, kojima se ne trguje na uređenom tržištu i koje se ne mogu lako i brzo prodati. Također, PE fond svu svoju likvidnost ostvaruje po odobrenom ulaganju i naknadnom pozivu na uplatu ulagateljima $\mathrm{u}$ fond, pa se u tom smislu rizik likvidnosti ogleda i u situacijama u kojima bi pojedini ulagatelji povrijedili svoju obvezu na uplatu iznosa (commitment). Prisutan je i rizik korištenja financijske poluge za realizaciju ulaganja i ostvarivanje maksimalnog povrata za fond, posebice kod nekih PE strategija. ${ }^{14}$ Značajan je i rizik nemogućnosti ulaganja u skladu s odabranom strategijom ako fond ne bi mogao realizirati adekvatnu priliku za ulaganje prema odabranoj i proklamiranoj strategiji ulaganja, iz bilo kojeg razloga (s obzirom na ograničeni vijek trajanja fonda i razdoblje ulaganja, to negativno utječe i na prinos fonda). Prisutan je i rizik uspješnosti ulaganja, koji, kao jedan od primarnih rizika za ulagatelje, proizlazi iz inicijalne procjene potencijalnog ulaganja te kasnijeg upravljanja ulaganjem. Budući da je taj rizik djelomično pod utjecajem PE fonda, on mora posvetiti iznimnu pažnju na postupak odabira ulaganja (provođenje sveobuhvatnog postupka dubinskog snimanja te komercijalne analize i procjene vrijednosti ulaganja, nastojanje da se osiguraju sve pravne i komercijalne pretpostavke za kasnije kvalitetno upravljanje ulaganjem i dr.). Valja spomenuti i rizik pranja novca i pronevjere, posebice u domeni konkretnih ulaganja (ne na razini društva za upravljanje), s čime je povezan i compliance rizik (zbog čega je za regulatora važno da prati postupaju li PE fond i društvo za upravljanje u skladu s propisima i internim procedurama). Osim navedenog, s PE fondovima povezan je i politički rizik jer PE fondovi često preuzimaju i restrukturiraju ciljna društva, što može dovesti do otpušta-

12 Tako i Čulinović-Herc; Braut Filipović; Audić Vuletić, op. cit. u bilj. 2, str. 54. Pritom napominjemo da neki od navedenih rizika postoje i kod drugih AIF-ova (primjerice, rizik nemogućnosti ulaganja u skladu s odabranom strategijom, rizik uspješnosti ulaganja i rizik likvidnosti).

13 Tako i Payne, op. cit. u bilj. 9, str. 6.

14 Wymeersch, op. cit. u bilj. 2, str. 25 i Davidoff, S. M., The Failure of Private Equity, Southern California Law Review, vol. 82, 2009., str. 481. 
nja, zatvaranja proizvodnje, promjene sjedišta društva i sl., što sve može uznemiriti lokalnu vlast te dovodi i do reputacijskog rizika za PE fond. Zbog svega navedenog može se zaključiti da su PE fondovi rizičniji od zloglasnih hedge fondova.

6. Za PE fondove također je karakteristično da su vrlo aktivni $i$ angažirani u odnosu na svoja ulaganja i ciljna društva (tzv. hands on), što znači da pomno prate ciljno društvo i s njim i njegovom upravom (i nadzornim odborom) u redovitoj su i vrlo bliskoj komunikaciji. Gledano kroz prizmu hrvatskog prava društava, takav angažman je vjerojatnije ostvariti kod d. o. o.-a, gdje uprava vodi poslove društva u skladu s društvenim ugovorom, odlukama članova društva i obveznim uputama skupštine i nadzornog odbora (ako ga društvo ima) ${ }^{15}$, nego kod d. d.-a, gdje uprava vodi poslove na vlastitu odgovornost. ${ }^{16}$ Osim toga, uzevši u obzir zakonske odredbe o nadležnosti uprave, nadzornog odbora i glavne skupštine d. d.-a i d. o. o.-a te iskorištavanju utjecaja u društvu ${ }^{17}$, razvidno je da se aktivitet i angažman PE fondova može ostvariti ponajprije izborom i imenovanjem članova nadzornog odbora, postavljanjem prokurista te eventualno imenovanjem članova uprave, i to posebice kod d. o. o.-ova.

Što se tiče equityja u koji se ulaže imovina PE fondova, kao najjednostavniji oblici ulaganja pojavljuju se redovne i povlaštene dionice. Povlaštene dionice često se odabiru za ulaganje PE fondova jer mogu biti različite s različitim pravima koja se realiziraju u različitim etapama ulaganja, posebice kod izlaza (npr. kumulativne, participirajuće, otkupive, konvertibilne). Postoje i instrumenti za koje se u praksi kaže da su "nalik vlasničkim instrumentima"18, a obuhvaćaju vrstu instrumenta financiranja koja je kombinacija equityja i duga, pri čemu je povrat od instrumenta povezan s dobiti ili gubitkom ciljnog društva, a otplata instrumenta u slučaju neispunjavanja obveza nije potpuno osigurana (te od kojih se, u svjetlu njihove podređenosti ili drugih posebnih okolnosti relevantnih ciljnih društava, očekuje prinos veći od prinosa uobičajenog nadređenog bankarskog financiranja). Takvi instrumenti uključuju, ali nisu ograničeni na različite instrumente financiranja kao što su: podređeni zajmovi (subordinated loans), tiho sudjelovanje (silent participation), sudjelujući zajmovi

15 Čl. 422. Zakona o trgovačkim društvima (Narodne novine, br. 111/1993, 34/1999, 121/1999, 52/2000, 118/2003, 107/2007, 146/2008, 137/2009, 125/2011, 152/2011, 111/2012, 68/2013, 110/2015, 40/2019; dalje u utekstu: ZTD).

16 Čl. 240., povezan s čl. 252. ZTD-a.

17 Vidi odredbe čl. 240. - 243., 250., 250.a, 252., 256., 273., 422., 434. i dr. ZTD-a.

18 Vidi čl. 29. st. 3. Pravilnika o vrstama alternativnih investicijskih fondova (Narodne novine, br. 28/2019 i 15/2020). 
(participating loans), prava na udio u dobiti (profit participating rights), zamjenjive obveznice (convertible bonds) i obveznice s varantima (bonds with warrants). Također postoje i složenije izvedenice koje počivaju na udjelima, dionicama ili obveznicama (tzv. delayed equity) ${ }^{19}$, od kojih u praksi mnogi nisu u primjeni na hrvatskom tržištu kapitala: opcije na dionice, udjele ili obveznice (call i put opcije), varanti ${ }^{20}$, mandatory convertibles ${ }^{21}$, deferred shares ${ }^{22}$, tracker shares/stocks ${ }^{23}$,

19 Vidi npr. https://www.researchgate.net/publication/325881915_Cheap_Debt_or_ Delayed_Equity_The_Motives_for_the_Use_of_Convertible_Bonds_By_Companies_in_Poland (19. travnja 2020.).

20 Varanti se često koriste jer daju pravo, ali ne i obvezu da se kupi financijski instrument po određenoj cijeni na određeni datum (call varanti, kao svojevrsna call opcija). Postoje i tzv. put varanti, koji daju pravo na prodaju financijskih instrumenata. Varanti se u praksi često izdaju upravi i zaposlenicima kako bi ih se potaknulo na bolji rad za uspjeh ciljnog društva, od kojeg će onda i oni sami imati koristi. Postoje i pokriveni varanti (covered warants) kod kojih se ne izdaju nikakvi novi financijski instrumenti, a oni su u svojoj osnovi kratkoročne izvedenice pokrivene novcem, dionicama ili opcijama, s time da ih izdaju razne financijske institucije, a ne ciljna društva.

21 To su u biti equity like instrumenti koji se mogu preoblikovati u redovne dionice $\mathrm{u}$ određenom vremenskom razdoblju (najčešće tri godine), oni nose određeni rizik, ali i mogućnost većeg prinosa, a često se izdaju kako bi se izbjeglo smanjivanje kreditnog rejtinga ciljnog društva. Vidi i Chemmanur, T. J.; Nandy, D.; Yan, A.; Jiao, J., A theory of mandatory convertibles, Journal of Banking and Finance, vol. 42, 2014. str. 352 i sl.; Chemmanur, T. J.; Nandy, D.; Yan, A., Why Issue Mandatory Convertibles?, Theory and Empirical Evidence, 2004., također i https://www.investopedia. com/terms/m/mandatoryconvertible.asp; https:/investinganswers.com/dictionary/m/ mandatory-convertible; https://www.euromoney.com/article/bl320w5kfgrz6r/thereturn-of-the-mandatory-convertible (19. travnja 2020.).

22 Dionice kod kojih se pravo na isplatu dividende i pravo glasa odgađaju na razdoblje do pet godina ili do njihova listanja na uređeno tržište. Najčešće se izdaju upravi i zaposlenicima kako bi ih se dodatno vezalo uz ciljno društvo. Ako ciljno društvo krene s uspješnim poslovanjem, to postaje obična redovna dionica. Vidi i https:// www.investopedia.com/terms/d/deferredshare.asp; https://uk.practicallaw.thomsonreuters.com/0-107-6070?transitionType $=$ Default\&contextData $=(\mathrm{sc}$. Default $) \&$ fir stPage $=$ true\& $b h c p=1 ;$ https://www.accountingweb.co.uk/any-answers/purpose-ofdeferred-shares (19. travnja 2020.).

23 Dionice koje ciljno društvo izdaje, a koje prate performanse samo pojedinog njegova dijela (npr. podružnice ili pojedinog odjela), a ne društva u cjelini i daju pravo na dividendu, ali ne daju nikakva "vlasnička" prava. Omogućuju ciljnom društvu da lakše proda dio svoga poslovanja ili podružnica i često se koriste u SAD-u. https://www.investopedia.com/terms/t/trackingstocks.asp; https://www.nasdaq.com/ glossary/t/tracking-stock. (19. travnja 2020.). 
portage equity ${ }^{24}$, synthetic ${ }^{25}$ i phantom equity, fully diluted equity. ${ }^{26} \mathrm{U}$ svakom od navedenih slučajeva poanta je da se s jedne strane imateljima udjela u ciljnom društvu omogući realizacija cjelokupnog ili barem dijela njihova udjela u kapitalu ciljnog društva, a s druge PE fondu omogući što lakša realizacija njegova ulaganja. U svim tim slučajevima za ciljno društvo nije potrebno pribavljati ili održavati kreditni rejting, a u njega se unosi određena vrijednost kako bi se omogućilo njegovo (daljnje) poslovanje ili poboljšalo njegovo poslovanje ili omogućilo širenje poslovanja, cijelo vrijeme bez financiranja od strane banaka. Tomu, u konačnici, i služi tržište kapitala, kao alternativni način financiranja.

Svrha i cilj PE fondova je pružanje kapitala, upravljačkoga iskustva i znanja društvima u koja se ulaže kako bi se njihova vrijednost stvorila ili povećala te se u konačnici, kroz odgovarajuću izlaznu strategiju, ostvario povrat ulaganja

24 Dionice koje daju pravo na fiksnu dividendu, a imaju uključenu i put opciju koja imatelju daje pravo da ih proda po određenoj cijeni trećoj strani. Načelno, ali i sa sasvim praktičnog aspekta, time se imatelji portage equityja dovode u povoljniju poziciju u odnosu na druge dioničare (jer imaju tu put opciju), zbog čega se takve transakcije i realiziraju kod PE ulaganja u privatnim društvima koja nisu listana na uređenom tržištu. Vidi i u Comparative Study of Equity Investing in Development Finance Institutions, Office of Evaluation and Oversight (OVE), ožujak 2017.

25 To je equity koji formalno ne postoji, nego je to u biti opcija na dionice, varante, ograničena dionica, odgođeno pravo na izdanje dionica ili neko drugo pravo koje svojemu imatelju omogućuje stjecanje dionica ciljnog društva u budućnosti. Kod phantom equityja zaposlenicima se (menadžment) putem raznih planova i ponuda daje mogućnost da sudjeluju u prihodima ciljnog društva ako ono ostvari određene ciljeve. Ako ih ciljno društvo ne ostvari, tada zaposlenici ništa ne dobivaju. U praksi se kod korištenja takvog tipa equityja javljaju određeni problemi zbog netransparentnosti jer se ne zna točno koliko je takvoga equityja, koliko vrijedi, kako se vrednuje, sami ciljevi mogu biti postavljeni nerealno, tko je imatelj toga i sl. https://www. lawinsider.com/dictionary/synthetic-equity; https:/www.businessinsider.com/synthetic-equity-ubs-2011-9; http://cdn.sqlogin.com/prod/sq_uploads/boldvalue.com/ documents/articles-for-inspiration/Synthetic-Equity-for-High-Performance-2019. pdf, https://www.investopedia.com/terms/p/phantomstock.asp i https://www.thebalance.com/how-phantom-stock-works-4159362 (19. travnja 2020.).

26 Obuhvaća ukupan broj redovnih dionica koje u jednom trenutku ciljno društvo može izdati i kojima se može trgovati nakon što se sav raspoloživi i postojeći equity konvertira $\mathrm{u}$ dionice (dakle, obuhvaća sve što u jednom trenutku može postati equity). Vidi https://www.investopedia.com/terms/f/fullydilutedshares.asp; https:// www.lawinsider.com/dictionary/fully-diluted-equity; https:/www.lathamdrive.com/ resources/insights/issued-and-outstanding-shares-versus-fully-diluted-shares; https://medium.com/@adjblog/understand-how-to-read-fully-diluted-shares-andtotal-outstanding-stock-in-a-cap-table-44e5a589322 (19. travnja 2020.). 
u srednjem ili duljem razdoblju. ${ }^{27}$ PE fondovi nastoje odabirom kvalitetnih ulaganja po povoljnim uvjetima i stjecanjem udjela u ciljnom društvu svojim iskustvom i ekspertizom unaprijediti njegovo poslovanje i upravljanje, čime bi se trebala povećati njegova vrijednost i ostvariti značajan dugoročni povrat na uložena sredstva.

\subsection{Strukture PE fondova}

U svijetu u različitim jurisdikcijama postoje različite strukture PE fondova, a pritom je bitno naglasiti da je PE tvorevina zemalja anglosaksonskog pravnog kruga, u prvom redu SAD-a. Zašto postoje različite strukture? Razlog je ponajprije porezne prirode. Poanta je oformiti strukturu PE fonda koja će onemogućiti oporezivanje na razini fonda (ili da to oporezivanje bude minimalno), dok je oporezivanje ulagatelja u fond moguće (oporezuje se prihod koji ulagatelji ostvare). ${ }^{28} \mathrm{Zbog}$ toga je u SAD-u ${ }^{29}$, Ujedinjenom Kraljevstvu, Nizozemskoj i Luksemburgu PE fond najčešće oformljen kao partnerstvo (partnership) i to (private) limited partnership koji sačinjavaju general partner i limited partner. U pravilu limited partnership nema pravnu osobnost, ali omogućuje ograničenu odgovornost limited partnera za obveze fonda, i to do visine njihova ulaganja u fond. General partner (glavni partner), pak, ima neograničenu odgovornost za obveze fonda. ${ }^{30} \mathrm{U}$ kontekstu investicijskih fondova limited partneri su ulagatelji u fond, dok je general partner u pravilu upravitelj fonda. General partner je najčešće oformljen kao subjekt posebne namjene (special purpose vehicle) u obliku limited liability company (LLC) kod kojeg osnivači odgovaraju ograničeno za obveze društva. Takve su strukture porezno vrlo transparentne i učinkovite jer se limited partneri u poreznom smislu tretiraju kao izravni imatelji udjela/dionica u društvima u koja se ulaže imovina. ${ }^{31}$

Opisana struktura (GP/LP) može biti i složenija, pa je moguće da se pojavi i manager, kao posebna osoba kojoj general partner delegira upravljanje imovinom

$27 \mathrm{U}$ tom smislu vidi i Report of the Alternative Investment Expert Group Developing European Private Equity, op. cit. u bilj. 2, str. 9.

28 Tako van Dam, M.; Mullmaier, J., Impact of AIFMD on the Private Equity Industry, u: Zetzche, D. A. (ur.), The Alternative Investment Fund Managers Directive, Second Edition, Kluwer Law International, 2015., str. 696 i 697.

29 Primjerice, u SAD-u je najveći broj PE fondova (gotovo $80 \%$ ) osnovan u obliku Delaware limited partnershipa (Private Equity Funds, Key Business, Legal and Tax Issues, op. cit. u bilj. 2, str. 28), a posljednjih je godina i Sjeverna Dakota postala prava meka za osnivanje PE fondova u SAD-u.

30 Tako i Čulinović-Herc; Braut Filipović; Audić Vuletić, op. cit. u bilj. 2, str. 53, 54 i 59.

31 Payne, op. cit. u bilj. 9. 
PE fonda i vlasnički je povezan s general partnerom. U tom slučaju general partner postaje sličan limited partneru jer više aktivno ne upravlja imovinom fonda, ali i dalje snosi odgovornost za upravljanje imovinom. Pritom treba imati na umu jednu posebnost PE fondova koja se, smatramo, u takvoj strukturi razvodnjava, ako ne i gubi. Naime, ulagatelji pristaju uložiti u PE fond (commitment) i svoj novac povjeravaju na upravljanje/ulaganje profesionalcu kojega su oni odabrali, u kojega imaju povjerenje, najčešće zato što taj profesionalac ima iza sebe konkretne rezultate (track record). Taj profesionalac odgovoran je za upravljanje njihovom imovinom, time i imovinom PE fonda, i tu je riječ o odnosu povjerenja ${ }^{32}$ koji nosi vrlo konkretne obveze u odnosu na upravitelja. Zbog toga se u gotovo svim dokumentima koji se sklapaju uvijek točno navode ključne osobe (key person), zahtjevi prema njima (posvećenost PE fondu, eventualne zamjene i sl.) i povrede od strane ključnih osoba (key person event) koje bi, primjerice, bile ako jedna od ključnih osoba prestane biti zaposlena ili na drugi način angažirana od strane upravitelja, a nije zamijenjena, ili prestane ispunjavati postavljene zahtjeve (u odnosu na posvećenost poslovnog vremena). Posljedice povrede mogu biti različite, ali tada PE fond najčešće ulazi u tzv. razdoblje suspenzije (kada se suspendiraju njegova ulaganja, nastavak ulaganja i raspolaganja ulaganjima, osim onih obveza ulaganja koje su nastale prije događaja koji je "aktivirao" razdoblje suspenzije). Razdoblje suspenzije može biti ukinuto i PE fond može nastaviti s normalnim radom ako se između upravitelja i ulagatelja postigne dogovor o jednoj ili više prikladnih zamjena ključnih osoba čim to bude moguće. No, ako nije došlo do zamjene relevantne ključne osobe u određenom roku, tada ulagatelji mogu smijeniti upravitelja PE fonda i zamijeniti ga drugim upraviteljem, pa čak i likvidirati PE fond. ${ }^{33}$

Za PE fondove je itekako bitno tko njima upravlja i komu su ulagatelji povjerili svoju imovinu, pa ako odabrani profesionalac prepusti upravljanje imovinom fonda - kao najvažniji dio njegova posla - trećoj osobi (manager), time se odnos povjerenja može narušiti i zbog toga je važno to urediti.

Između limited partnera i general partnera sklapa se niz ugovora koji uređuju partnerski odnos povjerenja, od kojih je najznačajniji Partnership agreement. Za Partnership agreement ne postoji univerzalna špranca ugovora, već je na dispoziciji samih ugovornih strana kako će taj ugovor u konačnici izgledati, a pritom je bitno kakvu pregovaračku moć imaju limited partneri (i imaju li je

32 Više o odnosu povjerenja i njegovim posebnostima u odnosu na tržište kapitala vidi Derenčinović Ruk, M., Odnos povjerenja u hrvatskom pravu, Hrvatska pravna revija, br. 10, 2016., str. 17.

33 Takve odredbe sadržavaju i pravila nekih hrvatskih PE fondova. 
uopće).$^{34}$ Postoji čitav niz radova koji se bave upravo tim odnosom te kritikom naspram general partnera ${ }^{35}$, koji su u pravilu u boljoj poziciji, a 2002. godine je formirana i Institutional Limited Partners Association (ILPA) kao udruga koja okuplja institucionalne limited partnere koji ulažu u PE-ove. ${ }^{36}$ Zbog toga je u praksi uobičajeno da se od samih upravitelja (general partner) traži i očekuje ulaganje u PE fond kojim upravlja (skin in the game) kako bi njihovi interesi bili što usklađeniji s interesima ulagatelja (limited partner). ${ }^{37}$ Iznos ulaganja general partnera u PE fond u praksi nije velik i kreće se oko jedan do dva posto, premda može ići i do pet posto udjela u fondu.

Osim Partnership agreementa, tu je još i Fund Membership (and management) agreement (najobuhvatniji dokument o kojem se i najviše pregovara jer sadržava odredbe o funkcioniranju fonda i njegovim ulaganjima), Investment Advisory agreement (ugovor koji uređuje pitanje savjetodavnih usluga, najčešće između general partnera/managera i PE fonda), Subscription agreement (dokument kojim ulagatelj preuzima obvezu ulaganja u PE fond, tj. daje svoj commitment) i Side Letter (zaseban dokument u kojem se uređuju posebna pitanja u odnosu na ulagatelje, primjerice informiranja i obavještavanja, porezna i regulatorna pitanja koja su važna za ulagatelje, prijenos prava i sl., a sklapa se između limited partnera i general partnera). ${ }^{38}$ Nije nužno da se sklapaju svi navedeni ugovori, to ovisi od fonda do fonda i povezano je s njegovom strukturom.

U odnosu na odgovornost general partnera kao upravitelja PE fondom važno je spomenuti i da se ponekad u Partnership agreementu predviđaju posebne odredbe kojima se umanjuje odgovornost general partnera prema limited partneru, čime se,

34 Primjerice, SW fondovi će zbog svoje veličine imati značajno snažniju pregovaračku moć u odnosu na manje fondove.

35 Vidi, primjerice, Davidoff, op. cit. u bilj. 14; Harris, op. cit. u bilj. 9; Banal-Estanol, A.; Ippolito, F., Contractual Terms and Conditions in Private Equity Partnership Agreements, November 2012.; Baks, K. P., Alignment of Interest in the Private Equity Industry, Emory Center for Alternative Investments, no. 7, 2010. U odnosu na ugovore i njihov sadržaj vidi i Chertok, S.; Braendel, A. D., Closed-end Private Equity Funds: A Detailed Overview of Fund Business Terms Part 1 and 2, Legal Studies Research Paper, no. 35, 2013. i no. 36, 2013.

36 ILPA je 2009. godine prvi put izdala ILPA Private Equity Principles, koji su u trećoj verziji izdani 2019. godine i kojima se nastoje objediniti najbolje prakse PE industrije usmjerene na poboljšanje te industrije za dugoročnu korist svih sudionika u industriji i korisnika. Vidi https://ilpa.org/wp-content/uploads/2019/06/ILPA-Principles-3.0_2019.pdf (19. travnja 2020.).

37 Payne, op. cit. u bilj. 9, str. 3 i 4.

38 Side letter nikada ne može dopuniti Fund agreement u odnosu na ostale ulagatelje u fond. Private Equity Funds, Key Business, Legal and Tax Issues, op. cit. u bilj. 2, str. 23. 
smatramo, dodatno potvrđuje i naglašava odnos povjerenja između general partnera i limited partnera. Premda to naoko djeluje kontradiktorno - nije, jer takvo ograničenje odgovornosti može biti samo rezultat dogovora i pregovora između general partnera i limited partnera budući da ono djeluje i ima svoje učinke samo među njima, ne djeluje prema trećima. Limited partner pristao je uložiti u PE fond i dati svoj commitment upravo stoga što njime upravlja određeni general partner (key person) i ako u konačnici dođe do nekih problema koji za sobom povlače odgovornost general partnera, ta odgovornost može biti i manja ako su oba partnera tako dogovorila i na to pristala. Takvo što nije moguće prema hrvatskim propisima koji striktno propisuju odgovornost društva za upravljanje naspram ulagatelja, kao i stupanj pažnje.

U Hrvatskoj je otvoreni AIF imovina bez pravne osobnosti, a zatvoreni može biti s pravnom osobnošću (samo d. d. ili d. o. o.), ili bez pravne osobnosti ${ }^{39}$, premda moguće je da se kod AIF-ova bez pravne osobnosti privatnopravni odnosi između ulagatelja u AIF-u posebnim sporazumom ${ }^{40}$ urede po pravilima ortaštva. Opisane strukture limited partnershipa najviše bi odgovarale komanditnom društvu, s time da bi general partner bio komplementar, a limited partneri komanditori. Gotovo sve odredbe ZTD-a idealno odgovaraju navedenoj strukturi PE fondova:

- Komanditno društvo je trgovačko društvo u koje se udružuju dvije osobe ili više osoba radi trajnog obavljanja djelatnosti pod zajedničkom tvrtkom od kojih najmanje jedna odgovara za obveze društva solidarno i neograničeno cijelom svojom imovinom (komplementar), a najmanje jedna odgovara za obveze društva samo do iznosa određenog imovinskog uloga u društvo (komanditor). ${ }^{41}$

- Društvom upravljaju komplementari, komanditori nisu ovlašteni upravljati poslovima društva (osnovni posao je, pritom, upravljanje imovinom) i komanditor se ne može usprotiviti odlukama ni postupcima komplementara, osim odlukama i postupcima koji se odnose ili se poduzimaju izvan granica redovnog poslovanja društva. ${ }^{42}$

- Isto vrijedi i za odredbe o pravu nadzora (komanditora nad komplementarom $)^{43}$, udjelu u dobiti i u gubitku ${ }^{44}$, isplati dobiti ${ }^{45}$, zastupanju ${ }^{46}$ i dr.

\footnotetext{
39 Prema odredbama čl. 4. t. 4. i 5. ZAIF-a.

40 Kao, primjerice, u slučaju dioničarskog sporazuma.

41 Čl. 131. ZTD-a.

42 Čl. 136. ZTD-a.

43 Čl. 137. ZTD-a.

44 Čl. 139. ZTD-a.

45 Čl. 141. ZTD-a.

46 Čl. 142. ZTD-a.
} 
U biti, razlika između komanditnog društva i limited partnershipa je u tomu što komanditno društvo ima pravnu osobnost. Većina hrvatskih PE fondova otvoreni su fondovi bez pravne osobnosti, a smatramo da bi, de lege ferenda, postojeći zakonodavni okvir svakako trebalo dopuniti i komanditnim društvom kao mogućim i dopuštenim oblikom zatvorenog AIF-a s pravnom osobnošću jer ta struktura više odgovara radu PE fondova, nego d. d. ili d. o. o. ${ }^{47}$

Osim navedenoga, PE fondovi u prvom se redu osnivaju kao zatvoreni fondovi, što znači da ulagatelji ne mogu prije određenoga vremena samo tako izaći iz fonda jer je otkup udjela ograničen ili čak onemogućen do prestanka rada fonda ili njegove likvidacije, a osim toga je i trgovanje udjelima u fondu ograničeno ili onemogućeno. ${ }^{48}$ Riječ je o fondovima udjelima kojih se ne trguje na uređenom tržištu, što utječe na likvidnost i transparentnost tih fondova. Postoje i otvoreni PE fondovi udjelima kojih se trguje na uređenom tržištu i koji mogu biti dostupni i malim ulagateljima. Kod takvih je PE fondova i struktura imovine ponešto drukčija jer ulagatelji imaju pravo tražiti otkup udjela u bilo koje vrijeme, pa u fondu mora biti više novca i ostale likvidne imovine kako bi se mogli zadovoljiti zahtjevi za otkupom. Uz to, otvoreni PE fondovi su i transparentniji što se tiče pružanja informacija, kako ulagateljima, tako i javnosti, upravo stoga što su listani na uređenom tržištu. No, sve to skupa utječe i na troškove otvorenih PE fondova, koji su zbog navedenoga veći.

\section{HRVATSKO PE ISKUSTVO I FONDOVI ZA GOSPODARSKU SURADNJU}

U rujnu 2020. godine situacija na području AIF-ova, tako i PE fondova, u Hrvatskoj je sljedeća ${ }^{49}$ :

1. 19 društava upravlja AIF-ovima.

2. Od 19 društava 11 ih upravlja samo AIF-ovima.

3. Od tih 11 društava četiri upravljaju PE fondovima, za što su specijalizirana. ${ }^{50}$

47 Tek u rujnu 2020. osnovan je AIF rizičnog kapitala s privatnom ponudom kao zatvoreni AIF - Prosperus Growth.

48 Vidi Private Equity Funds, Key Business, Legal and Tax Issues, op. cit. u bilj. 2, str. 4; Banal-Estanol; Ippolito, op. cit. u bilj. 35, str. 2.

49 Prema podacima s internetske stranice Hanfe (registri).

50 FGS-ovi su Quaestus Private Equity d. o. o., Prosperus Invest d. o. o., Fima Invest d. o. o. (prije Honestas Private Equity Partneri d. o. o.) i Inspire Investments d. o. o. (društvo je osnovano 2016. godine). Preostala dva PE fonda su AIF podu- 
4. Ta četiri društva upravljaju sa sedam PE fondova.

5. Od sedam PE fondova pet su fondovi za gospodarsku suradnju. ${ }^{51}$

Ukupna vrijednost neto imovine pod upravljanjem PE fondova u Hrvatskoj (zbirno za sve PE fondove na 30. lipnja 2020., uključujući FGS-ove) iznosi $528.519 .476,17 \mathrm{kn}^{52}$, što je 12,01 \% vrijednosti imovine svih AIF-ova u Hrvatskoj. Usporedbe radi, europska private equity industrija upravlja s otprilike 690 milijardi eura, dok na svjetskoj razini govorimo o 4 trilijuna američkih dolara vrijednosti imovine pod upravljanjem PE fondova. ${ }^{53}$

\section{2.l. Razvoj zakonskog uređenja PE fondova u Hrvatskoj i njegove posebnosti}

Počeci zakonskog uređenja poslovanja PE fondova i društava koja njima upravljaju sežu u 2005., kada je na snagu stupio stari Zakon o investicijskim fondovima. ${ }^{54}$ Kao fondovi s privatnom ponudom mogli su se osnivati samo otvoreni fond s privatnom ponudom i otvoreni fond rizičnog kapitala s privatnom ponudom. ${ }^{55}$ ZIF je u Glavi XI. uređivao fond rizičnog kapitala, koji je bio definiran kao zasebna imovina bez pravne osobnosti, koju uz odobrenje nadzornog tijela osniva društvo za upravljanje otvorenim fondovima rizičnog kapitala s privatnom ponudom s ciljem prikupljanja novčanih sredstava i privatnom ponudom udjela $u$ fondu, čija se sredstva ulažu u skladu s ciljevima ulaganja i ograničenjima ulaganja utvrđenim prospektom fonda te čiji imatelji udjela imaju pravo, osim prava na

zetničkog kapitala s privatnom ponudom Feelsgood investicijski fond s društvenim učinkom (venture capital fond) i AIF rizičnog kapitala s privatnom ponudom Prosperus Growth. Također, 28. veljače 2020. Hanfa je odobrila i osnivanje društva INVERA EQUITY PARTNERI d. o. o., koje za početak ne bi osnivalo PE fond u Hrvatskoj, nego bi preuzelo upravljanje PE fondom iz Nizozemske, što bi ujedno bio i prvi slučaj prekograničnog poslovanja jednog društva za upravljanje AIF-ovima u Hrvatskoj (vidi https://tockanai.hr/poduzetnik/financiranje/invera-private-equity-fond-24837/; https://www.tportal.hr/biznis/clanak/ebrd-ulaze-10-milijuna-eura-u-private-equity-fond-20190709; https://www.ebrd.com/work-with-us/projects/ psd/invera-private-equity-fund.html) (19. travnja 2020).

51 Riječ je o fondovima Honestas FGS, Inspirio ALPHA (prije NEXUS ALPHA), Inspirio FGS (prije Nexus FGS), Prosperus FGS, Prosperus FGS II (prije Nexus FGS II), Quaestus Private Equity Kapital II.

52 Prema mjesečnim izvještajima dostupnim na internetskim stranicama Hanfe.

53 Prema podacima https://www.opalesque.com/677547/Private_equity_assets_under_ management_crosses754.html i Invest Europe za 2019. godinu (19. travnja 2020.).

54 Narodne novine, br. 105/2005; dalje u tekstu: ZIF.

55 Čl. 13. ZIF-a. 
razmjerni udio u dobiti fonda, na način i pod uvjetima utvrđenim prospektom fonda, zahtijevati isplatu udjela i na taj način istupiti iz fonda. ${ }^{56}$ Definicija je dosta široka i djelomično se podudara s današnjom definicijom AIF-a iz ZAIF-a ${ }^{57}$ te iz nje nije razvidno po čemu se to ona odnosi na PE fondove. No, ZIF je vrlo detaljno uređivao fondove rizičnog kapitala kroz 21 članak, pa je iz tih odredaba, posebice onih o trajanju fonda, dozvoljenim ulaganjima (investicijska strategija) i ulagateljima u fond bilo vidljivo da je riječ o ulaganjima svojstvenima PE fondovima, posebice kada se u obzir uzme činjenica da su se u Hrvatskoj mogli osnivati samo oni fondovi koji su bili predviđeni ZIF-om, kao i dozvoljena ulaganja svih fondova. ZIF-om je bilo propisano ${ }^{58}$ :

- Da se fondovi mogu osnovati samo na određeno vrijeme koje ne može biti kraće od 10 godina.

- Veličina fonda mora iznositi najmanje 75.000.000,00 kuna, a podrazumijeva upisanu maksimalnu obvezu uplate svih ulagatelja po svim osnovama kroz cijelo vrijeme trajanja fonda.

- Pristup novih ulagatelja fondu nije moguć nakon isteka dvije godine od osnivanja fonda.

- Prilikom osnivanja fonda udjeli smiju biti nuđeni privatnom ponudom isključivo osobama kojima se priznaje status kvalificiranih ulagatelja u fondove rizičnog kapitala. ${ }^{59}$

- Prospektom i statutom fonda mogao se odrediti najveći dopušteni broj ulagatelja u fond, a moglo ih je biti najviše 20 .

- Najniži iznos maksimalne obveze uplate pojedinog ulagatelja u fond iznosi 10.000 .000 kuna, koju je ulagatelj dužan izvršiti po pozivima društva za upravljanje prema odredbama prospekta. ${ }^{60}$

56 Čl. 202. ZIF-a.

57 Vidi čl. 4. t. 3. ZAIF-a i bilješku 3.

58 Čl. 203., 209., 210., 212. i 213. ZIF-a.

59 Čl. 2. ZIF-a definirao je kvalificirane ulagatelje u fondove rizičnog kapitala kao ulagatelje koji na temelju važećeg odobrenja posluju kao investicijski ili mirovinski fond, kao društvo za upravljanje investicijskim ili mirovinskim fondom, kao banka ili kao osiguravajuće društvo ili kao brokersko društvo te sva druga trgovačka društva ili fizičke osobe, s tim da neto vrijednost imovine tih društava i fizičkih osoba prelazi 20.000.000,00 kuna i koji za potrebe ulaganja u određeni investicijski fond raspolažu gotovim novcem u iznosu od najmanje 10.000.000,00 kuna.

${ }_{60}$ Čak je bilo propisano da u slučaju da ulagatelj po pozivu društva ne izvrši uplate do maksimalnog iznosa ulagatelj ne može zahtijevati iskup svojih udjela sve do konačnog isteka roka na koji je fond osnovan odnosno likvidacije fonda i iskupa svih udjela (čl. 203. st. 7. ZIF-a). 
- Najniži iznos neto imovine fonda na dan isteka pete godine od dana osnivanja ne može biti manji od 50 \% veličine fonda (dakle 37.500.000 kuna).

- Određene su naknade koje se naplaćuju ulagatelju i fondu (ulazna, izlazna i naknada za upravljanje, a jedan dio naknade za upravljanje smije biti utvrđen tako da ovisi o prinosu fonda).

- Propisana su čak i dozvoljena ulaganja (udjeli i dionice trgovačkih društava, novčana sredstva i dani zajmovi) te vrlo detaljna ograničenja ulaganja i zaduživanja. ${ }^{61}$

Osim navedenog, ZIF je propisao još jednu zanimljivost, a to je obveza postojanja povjereničkog odbora ${ }^{62}$ kao tijela koje čine predstavnici ulagatelja u fond i pred-

${ }^{61}$ Čl. 213. ZIF: (1) Ulaganje imovine i zaduživanje otvorenoga investicijskog fonda rizičnog kapitala s privatnom ponudom podliježe sljedećim ograničenjima:

1. u roku od pet godina nakon osnivanja fonda, fond mora napraviti minimalno pet investicija u različite udjele ili dionice s tim da udjeli ili dionice jednog izdavatelja ne smiju prelaziti 33 \% veličine fonda definirane u članku 203. stavku 2. ovoga Zakona,

2. u slučaju neispunjenja broja investicija iz točke 1. ovoga članka, Povjerenički odbor će u roku od 60 dana od isteka roka iz stavka l. ovoga članka odabrati novo društvo za upravljanje s tim da broj investicija na dan isteka jedne godine nakon odabira novog društva za upravljanje ne može biti manji od pet,

3. u slučaju neispunjenja kriterija iz točke 2. ovoga članka, Nadzorno tijelo će donijeti odluku o likvidaciji fonda u skladu s odredbama članka 181. do 185. ovoga Zakona,

4. ulaganje u jedan gospodarski sektor ne može iznositi više od 40 \% veličine fonda definirane u članku 203. stavku 2. ovoga Zakona,

5. osobe koje čine povezana društva sukladno odredbama ovoga Zakona smatraju se jednim izdavateljem u smislu točke l. ovoga članka,

6. nije dozvoljeno ulaganje u vrijednosne papire koji su uvršteni na burzu s namjerom kratkoročnog trgovanja,

7. najviše do $75 \%$ veličine fonda definirane u članku 203. stavku 2. ovoga Zakona, fond može uzimati kredite,

8. dani depoziti bankama i uzeti krediti od banaka od strane fonda ne mogu se naplaćivati niti otplaćivati preuzimanjem udjela ili dionica izdavatelja koje su banke prethodno stekle u vlasništvo ili na njih imaju prethodno upisano založno pravo.

(2) Društvo za upravljanje mora u prospektu fonda jasno naznačiti politiku ulaganja i klase imovine u koju namjerava ulagati, uključujući i stupanj financijske izloženosti fonda riziku koji proizlaze iz zaduživanja.

Osim citiranih zakonskih odredaba postojao je i Pravilnik o dozvoljenim ulaganjima i ograničenjima ulaganja otvorenih investicijskih fondova rizičnog kapitala $s$ privatnom ponudom (Narodne novine, br. 7/2007). 
stavnici društva za upravljanje (ako je društvo jedan od ulagatelja). Povjerenički odbor ima najmanje pet članova i zastupa ulagatelje u fond prema društvu za upravljanje te obavlja i druge poslove koji su mu na temelju ZIF-a stavljeni u nadležnost, a osobito potvrđuje odluku o izboru revizora poslovanja fonda, odlučuje o promjeni načela, ograničenja i sektora ulaganja koja su sastavni dio statuta fonda, usvaja financijske izvještaje o poslovanju fonda, donosi odluku o otkazu društvu za upravljanje te daje druge suglasnosti i odobrenja društvu prema statutu fonda. Povjerenički odbor fonda može zahtijevati od društva za upravljanje da ga izvješćuje i o stanju portfelja fonda i investicijskim mogućnostima te o drugim okolnostima bitnim za stvaranje suda o upravljanju imovinom fonda. Zakonsko propisivanje obveze ustrojavanja odbora s takvim ovlastima inače nije uobičajeno. U praksi je uobičajeno postojanje savjetodavnih odbora (advisory board), ali je formiranje takvog odbora mogućnost, a ne obveza, a njegova je uloga upravo onakva kako sam naziv govori - savjetodavna, pa će u praksi savjetodavni odbor savjetovati upravitelja PE fonda o vrednovanju imovine fonda, sukobu interesa ${ }^{63}$ i nekim drugim pitanjima koja mu se stave $u$ nadležnost, o čemu će davati svoje preporuke i osvrte, ali ne i obvezujuće upute jer je upravitelj fonda zadužen za upravljanje fondom i tzv. day to day management. Postoji mogućnost da ulagatelji putem savjetodavnog odbora i imaju određeni utjecaj na fond, no taj utjecaj nikada nije takav da bi se odlučivalo o konkretnim ulaganjima, vrednovanjima i sl., nego više služi kao orijentir (npr. fokusiranje na ulaganje u određeni tržišni sektor i sl.).

Dakle, Hrvatska je od samoga početka točno odredila formu, način i okvire rada i ulaganja PE fondova, kao i njihovih upravitelja. ${ }^{64}$ Pritom napominjemo da je riječ bila upravo o zakonskom uređenju rada PE fondova, što AIFM Direktiva ne čini - ona je usmjerena na uređenje rada upravitelja fondova te ni ne predviđa moguće oblike i strategije rada AIF-ova. ${ }^{65}$ Prilikom prenošenja AIFM Direktive u hrvatsko zakonodavstvo 2013. učinjen je značajan napredak te stari ZAIF više nije sadržavao odredbe o dozvoljenim ulaganjima i ograničenjima ulaganja AIF-ova, niti o njihovoj strukturi, no stari Pravilnik o vrstama AIF-ova ${ }^{66}$ i dalje je propisivao dozvoljena ulaganja i ograničenja ulaganja otvorenog i zatvorenog

${ }_{63}$ Vidi Harris, op. cit. u bilj. 9, str. 270.

64 Belgija i Danska su također propisima odredile posebne forme fondova koje se mogu koristiti za PE ulaganja, vidi Wymeersch, op. cit. u bilj. 2, str. 24.

65 U Dodatku IV. Delegirane uredbe 231/2013 navode se strategije ulaganja alternativnih investicijskih fondova, pa tako i fondovi rizičnog kapitala (private equity / venture capital).

66 Narodne novine, br. 105/2013 i 28/2015; dalje u tekstu: stari Pravilnik o vrstama AIF-ova. 
AIF-a s javnom ponudom ${ }^{67}$, zatvorenog AIF-a s javnom ponudom za ulaganje u nekretnine te osnovni okvir ulaganja za AIF-ove s privatnom ponudom. Taj je pravilnik pobrojao vrste AIF-ova s privatnom ponudom, koja lista nije bila numerus clausus, i među njima su kao posebne vrste AIF-a s privatnom ponudom bili navedeni AIF rizičnog kapitala (private equity) te AIF poduzetničkog kapitala (venture capital). Pravilnik je, također, propisao da se u pravilima AIF-a s privatnom ponudom može propisati postojanje odbora koji čine predstavnici ulagatelja, poslove koje on obavlja, način rada i broj članova odbora ${ }^{68}$, čime je ostavljena mogućnost daljnjeg postojanja povjereničkih odbora iz starog ZIF-a. Pravilnik je definirao AIF rizičnog kapitala (private equity) kao AIF s privatnom ponudom čija se imovina, u skladu s pravilima AIF-a, pretežito ulaže u poslovne subjekte s ciljem optimiziranja njihove poslovne i financijske uspješnosti, a u očekivanju realiziranja povrata na uložena sredstva, dok ulaganja AIF-a u poslovne subjekte moraju biti u obliku vlasničkih instrumenata ili instrumenata nalik vlasničkim instrumentima. ${ }^{69}$

Dodatni napredak učinjen je 2018. donošenjem ZAIF-a, pa danas i Pravilnik o vrstama AIF-ova ${ }^{70}$ propisuje samo dozvoljena ulaganja otvorenog i zatvorenog AIF-a s javnom ponudom te nekretninskog AIF-a, dok se odredbe o PE fondovima nisu mijenjale, ali su dodani uvjeti za AIF-ove koji u svrhu ulaganja koriste subjekt posebne namjene (SPV). ${ }^{71}$

\subsection{Prvo hrvatsko društvo za upravljanje PE fondovima i prvi hrvatski PE fond (Quaestus)}

Početak razvoja PE tržišta u Hrvatskoj vezan je uz djelovanje stranih PE fondova koji su bili organizirani kao lokalne konzultantske kompanije stranih

67 Upravo zato što je bila riječ o fondovima s javnom ponudom, koji su namijenjeni i malim ulagateljima jer su tzv. UCITS like.

68 Čl. 17. starog Pravilnika o vrstama AIF-ova.

69 Čl. 20. starog Pravilnika o vrstama AIF-ova. U čl. 22. propisana su i ograničenja ulaganja i zaduživanja AIF-a rizičnog kapitala, dok je u čl. 24. dana definicija AIF-a poduzetničkog kapitala (venture capital) kao AIF-a s privatnom ponudom čija se imovina, u skladu s pravilima AIF-a, pretežito ulaže u poslovne subjekte koji su novoosnovani ili su u početnim fazama poslovanja, a prema procjeni UAIF-a pokazuju potencijal za rast i širenje poslovanja.

70 Narodne novine, br. 28/2019 i 15/2020.

71 Čl. 28. novog Pravilnika o vrstama AIF-ova. 
PE upravitelja kao što su SEAF Croatia, Horizonte Venture Mangement, Copernicus Capital i Vienna Capital Partners. ${ }^{72}$

Prvo društvo koje se u Hrvatskoj počelo baviti upravljanjem PE fondova je Quaestus Private Equity d. o. o., osnovano dvije godine prije stupanja na snagu ZIF-a (dakle 2003. godine), nakon čega je usklađeno sa ZIF-om. ${ }^{73}$ Prvi PE fond u Hrvatskoj bio je Quaestus Private Equity Kapital, čije je osnivanje odobreno rješenjem Hrvatske agencije za nadzor financijskih usluga (dalje u tekstu: Hanfa) od 2. lipnja 2006. Fond je osnovan na razdoblje od deset godina, a u prosincu 2016. produljeno je trajanje fonda za dvije godine te je fond prestao s radom u svibnju 2018. Ciljana veličina fonda bila je 35 milijuna eura, a taj je iznos i prikupljen. Ciljevi toga fonda prema prospektu bili su $\mathrm{su}^{74}$ :

- ulaganjem u različita društva i poboljšanjem njihove dugoročne pozicije na tržištu dostići prosječnu godišnju internu stopu rentabilnosti (ISR) od preko $25 \%$

- ulaganje u pravilu u srednje velika društva čije je sjedište ili posluju na području Republike Hrvatske, Slovenije, Bosne i Hercegovine te Srbije, Crne Gore i Makedonije

- ulaganja koja omogućuju doprinos razvitku društava u koja se ulaže

- ulaganja kojima će se stjecati udjeli u društvima koji će fondu omogućavati utjecaj na upravljanje društvima u koja se ulaže i

- visok stupanj kontrole strategije izlaza.

Prema prospektu fonda primarni investicijski cilj fonda bila su vodeća trgovačka društva srednje veličine koja po potencijalu nadmašuju ostala trgovačka društva u svojoj grani, uživaju određenu efektivnu zaštitu od ulaska konkurenata na njihovo tržište, imaju potencijalno značajan i rastući udjel na domaćem tržištu te potencijalno superioran i motiviran menadžment. Kako bi se iskoristile najbolje moguće prilike na relativno malom tržištu, fond je nastojao prakticirati fleksibilan pristup investiranju u različite sektore. Ciljane kategorije ulaganja uključuju:

- kupnju i poboljšanje poslovanja postojećih društava

72 Šimić, op. cit. u bilj. 1, str. 280. Neka od društava u koja su uložili su Medifarm, Bello, Klik Multimedija, Uzgoj, Vimi, GlobalNet, Electronic CATV, Adriatic kabel IVB itd.

73 Prije stupanja na snagu ZIF-a to društvo poslovalo je kao običan d. o. o., koji je putem d. o. o.-ova i provodio svoja ulaganja. Nakon stupanja na snagu ZIF-a poslovanje je usklađeno s fondovskom regulativom.

74 Vidi i https://www.quaestus.hr/o-nama/rizicni-kapital/investicijska-strategija/ (26. travnja 2020.). 
- objedinjavanje manjih društava radi stvaranja većih i efikasnijih

- udruživanja sa strateškim partnerima pri kupnji većih društava

- privatizacije te

- početni kapital i kapital za proširenje poslovanja.

Fond je, prema prospektu, nastojao realizirati vlasnička i s vlasništvom povezana ulaganja, uključujući management buy-out i managment buy-in transakcije. Planirana su ulaganja uglavnom u vrijednosti od 2 do 5 milijuna eura po transakciji i da se sastoje u prvom redu od razvojnog kapitala u obliku direktnog vlasničkog ulaganja u postojeća trgovačka društva. Bitan uvjet je utjecajna vlasnička pozicija i mogućnost visokog stupnja kontrole strategije izlaza. Najmanji prihvatljivi udjel u pravilu je udjel s pravom blokiranja odluka. Fond će u pravilu imati svoje predstavnike $\mathrm{u}$ nadzornom odboru.

U nastavku se u tabličnom prikazu donose ulaganja prvog hrvatskog PE fonda.

\section{Tablica 1.: Ulaganja fonda Quaestus Private Equity Kapital}

\begin{tabular}{|c|c|c|c|c|c|}
\hline \multicolumn{6}{|c|}{ QUAESTUS PRIVATE EQUITY KAPITAL } \\
\hline društvo & sektor & opis & $\begin{array}{c}\text { tip } \\
\text { ulaganja }\end{array}$ & $\begin{array}{l}\text { datum } \\
\text { ulaganja }\end{array}$ & $\begin{array}{l}\text { datum } \\
\text { izlaska }\end{array}$ \\
\hline Tele2 d. o. o. & telekomunikacije & $\begin{array}{l}\text { mobilni } \\
\text { operater }\end{array}$ & $\begin{array}{l}\text { vlasnički } \\
\text { kapital }^{75}\end{array}$ & $5 / 2005$ & $6 / 2009$ \\
\hline $\begin{array}{l}\text { GFG Gustus d. о. о. } \\
\text { (Daily Fresh) }\end{array}$ & uslužni & $\begin{array}{l}\text { restorani } \\
\text { brze hrane }\end{array}$ & $\begin{array}{l}\text { vlasnički } \\
\text { kapital }\end{array}$ & $9 / 2007$ & $4 / 2011$ \\
\hline Hlad d. o. o. & proizvodnja hrane & $\begin{array}{l}\text { proizvodnja } \\
\text { smrznutog } \\
\text { voća }\end{array}$ & $\begin{array}{l}\text { vlasnički } \\
\text { kapital }\end{array}$ & $4 / 2007$ & $4 / 2014$ \\
\hline Vulić\&Vulić d. о. o. & proizvodnja hrane & $\begin{array}{l}\text { proizvodnja } \\
\text { smrznutog } \\
\text { voća } \\
\end{array}$ & $\begin{array}{l}\text { vlasnički } \\
\text { kapital }\end{array}$ & $3 / 2008$ & $7 / 2014$ \\
\hline $\begin{array}{l}\text { Metronet } \\
\text { telekomunikacije d. d. }\end{array}$ & telekomunikacije & $\begin{array}{l}\text { alternativni } \\
\text { telekom }\end{array}$ & \begin{tabular}{|l} 
vlasnički \\
kapital
\end{tabular} & $5 / 2005$ & $2 / 2017$ \\
\hline $\begin{array}{l}\text { Akromion d. o. o. } \\
\text { (Osteon d. o. o.) }\end{array}$ & zdravstvene usluge & $\begin{array}{l}\text { ortopedska } \\
\text { bolnica }\end{array}$ & $\begin{array}{l}\text { vlasnički } \\
\text { kapital }\end{array}$ & $4 / 2007$ & $4 / 2017$ \\
\hline $\begin{array}{l}\text { Hospitalija trgovina } \\
\text { d. o. o. }\end{array}$ & $\begin{array}{l}\text { veleprodaja } \\
\text { medicinskih } \\
\text { proizvoda }\end{array}$ & $\begin{array}{l}\text { distribucija } \\
\text { medicinskih } \\
\text { proizvoda }\end{array}$ & $\begin{array}{l}\text { vlasnički } \\
\text { kapital }\end{array}$ & $9 / 2004$ & $11 / 2017$ \\
\hline
\end{tabular}

Izvor: Društvo za upravljanje Quaestus Private Equity d. o. o.

75 Na mrežnim stranicama društava za upravljanje, kao i u njihovim očitovanjima na upitnik te u svakodnevnom govoru, koristi se izraz "vlasnički kapital" koji formalnopravno (s aspekta prava društava) znači ulaganje u temeljni kapital društva, tj. u vlastiti kapital društva. 
Iz navedenih je podataka vidljivo da je fond Quaestus Private Equity Kapital izvršio sedam ulaganja te da je prosjek trajanja ulaganja (ostanka u investiciji) bio osam godina, s time da je taj prosjek manji za ulaganja u uslužni sektor i proizvodnju hrane (pet godina), a veći u području zdravstvenih usluga i usluga povezanih s medicinskim proizvodima. Za ulaganje u područje telekomunikacija teško je odrediti prosjek jer je društvo Metronet telekomunikacije d. d. prošlo postupak predstečajne nagodbe u kojem je uspješno restrukturirano. Fond je ulaganja poduzeo u prve dvije godine životnog ciklusa. Sva su ulaganja izvršena izravno (bez društva posebne namjene - SPV), a prema navodima društva za upravljanje bilo je i negativnih iskustava s ulaganjem u obiteljska društva jer je "obiteljskog poduzetnika" teže uvjeriti da dio udjela prepusti PE fondu, za razliku od društava s raspršenijom vlasničkom strukturom, a i kod izlaza iz ciljnog društva može doći do razmimoilaženja interesa PE fonda i partnera (s obzirom na to da tu partneri obično planiraju isplatiti PE fond i vratiti to ciljno društvo natrag u svoje ruke), pa takva situacija može nepovoljno utjecati na prinos fonda. Od sedam ulaganja samo je jedno ostvarilo pozitivnu internu stopu povrata.

\subsection{Drugo hrvatsko društvo za upravljanje PE fondovima i drugi hrvatski PE fond (Nexus)}

Drugo društvo za upravljanje PE fondovima bilo je Nexus Private Equity Partneri d. o. o., koje je odobrenje za rad Hanfe dobilo u veljači 2008. godine, a u kolovozu 2008. godine osnovalo je svoj prvi PE fond Nexus Alpha. Ciljana veličina fonda bila je 400 milijuna kuna, a prikupljeno je oko 270 milijuna kuna. Prema prospektu fonda investicijski ciljevi fonda bili su:

- ostvariti prosječnu godišnju internu stopu povrata na uložena sredstva fonda za ulagatelje veću od $20 \%$

- ulaganjem sredstava generirati novu, dodatnu vrijednost u društvu u koje ulaže

- osigurati utjecaj na upravljanje u društvima u koja se ulaže u svrhu ostvarivanja poslovnih planova od obostranog interesa

- osigurati visoki stupanj autonomije strategije izlaza (dezinvestiranja)

- nastojati diversificirati rizike ulaganjem u različita društva koja posluju ili na različitim tržištima ili/i u različitim sektorima gospodarstva, odnosno tržišnim nišama.

Prospektom fonda kao mogući modaliteti stjecanja vlasničkog udjela u pojedinom trgovačkom društvu su, među ostalim, predviđeni management buy-out, management buy-in, buy-in management buy-out, kao kombinacija MBO-a i MBI-ja, 
institutional buy-out te općenito leveraged buy-out, privatizacijski procesi, dokapitalizacija i zajednički nastup sa strateškim partnerom (partnerima).

Tablica 2.: Ulaganja fonda Inspirio Alpha (Nexus Alpha)

\begin{tabular}{|c|c|l|l|l|l|}
\hline \multicolumn{5}{|c|}{$\begin{array}{c}\text { INSPIRIO ALPHA* } \\
\text { (NEXUS ALPHA) }\end{array}$} \\
\hline društvo & sektor & \multicolumn{1}{|c|}{ opis } & $\begin{array}{c}\text { tip } \\
\text { ulaganja }\end{array}$ & $\begin{array}{c}\text { datum } \\
\text { ulaganja }\end{array}$ & $\begin{array}{c}\text { datum } \\
\text { izlaska }\end{array}$ \\
\hline Promotehna d. o. o. & distribucija & $\begin{array}{l}\text { distribucija } \\
\text { specijalizirane } \\
\text { opreme za } \\
\text { autoindustriju }\end{array}$ & $\begin{array}{l}\text { vlasnički } \\
\text { kapital }\end{array}$ & $6 / 2009$ & $1 / 2018$ \\
\hline Aqua-Maritime d. o. o. & maloprodaja & $\begin{array}{l}\text { maloprodaja } \\
\text { tekstila i dizajn }\end{array}$ & $\begin{array}{l}\text { vlasnički } \\
\text { kapital }\end{array}$ & $11 / 2009$ & $7 / 2018$ \\
\hline Kozmo d. o. o. & maloprodaja & $\begin{array}{l}\text { maloprodaja } \\
\text { kozmetike i ostalo }\end{array}$ & $\begin{array}{l}\text { vlasnički } \\
\text { kapital }\end{array}$ & $12 / 2009$ & $4 / 2015$ \\
\hline * fond je likvidiran u 5/2020, više ne postoji &
\end{tabular}

Izvor: Društvo za upravljanje Inspire Investments d. o. o.

Iz navedenih je podataka vidljivo da je fond Inspirio Alpha izvršio samo tri ulaganja te da je prosjek trajanja ulaganja više od šest godina. Fond je poslovao gotovo 12 godina $(10+2)$, a sva su ulaganja bila u segmentu malog i srednjeg poduzetništva (SME), s time da su dva ulaganja bila u obiteljska društva. Sva su ulaganja bila izravna (bez društva posebne namjene - SPV) uz korištenu Growth/ Expansion strategiju i isključivo putem vlasničkog kapitala. Prema podacima prikupljenima od društva koje je upravljalo fondom, sva su tri ulaganja fonda prodana po cijeni manjoj od troška stjecanja (dakle ne možemo ni govoriti o ostvarenju povrata za ulagatelje) te je nakon gotovo 12 godina rada fonda omjer isplate ulagateljima bio 69 \% (na svaku uloženu kunu ulagatelji su u konačnici dobili 69 lipa). Sva tri ciljna društva prodana su strateškom partneru. Društvo za upravljanje je putem upitnika kao ključne probleme fonda istaknulo transakcije s povezanim osobama, neodgovarajuće utvrđena pravila korporativnog upravljanja te nedostatak kontrole (od strane društva za upravljanje) u operativnoj provedbi - primjerice, društvo za upravljanje nije imalo nikakvu stvarnu kontrolu, ni utjecaj na način vođenja i upravljanja jednim ciljnim društvom, dok su kod preostala dva ciljna obiteljska društva osnivači ostali manjinski partneri, ali s dominantnim upravljačkim pravima koja su se u praksi provodila na operativnoj razini gotovo bez ikakvog utjecaja i kontrole društva za upravljanje, što je rezultiralo sukobom u situaciji dovođenja društva u lošu poslovnu situaciju i istiskivanjem manjinskog partnera te predstečajne nagodbe. 


\subsection{Venture capital fond - Inspirio Fusion (Inspire Fusion) ${ }^{76}$}

Osvrnut ćemo se i na slučaj venture capital fonda Inspirio Fusion (inicijalno Inspire Fusion), koji je u lipnju 2016. osnovalo društvo za upravljanje Inspire Investments d. o. o. I taj fond, nažalost, više ne postoji jer je likvidiran u listopadu 2018. Pravila fonda su kao temeljni cilj fonda odredila rast vrijednosti udjela $\mathrm{u}$ fondu, razmjerno preuzetom riziku, a društvo za upravljanje težilo je ostvarenju apsolutnog prinosa (ostvarenje pozitivnog prinosa neovisno o ostvarenim prinosima pojedinih klasa imovine) alokacijom prikupljenih novčanih sredstva fonda u sve dozvoljene vrste imovine, koristeći se pritom potrebnim tehnikama za učinkovito upravljanje portfeljem (kolateral, obrnute repo sporazume i primljene garancije). Investicijska strategija fonda trebala se ostvariti kroz ulaganje imovine fonda u poslovne subjekte koji su novoosnovani ili su u početnim fazama poslovanja, a prema procjeni društva pokazuju potencijal za rast i širenje poslovanja, koji:

- nisu uvršteni, niti se njima trguje na uređenom tržištu ili MTP-u u Hrvatskoj, državi članici i/ili trećoj državi, u vrijeme kada se isti stječe za račun fonda

- imaju manje od 250 zaposlenih radnika, ostvaruju manje od 400 milijuna kuna prihoda godišnje i čija ukupna aktiva iznosi najviše 344 milijuna kuna

- nisu subjekti za zajednička ulaganja

- nisu kreditna institucija, financijski holding niti mješoviti holding, investicijsko društvo te osiguravajuće društvo

- imaju sjedište u Hrvatskoj, drugoj državi članici ili u trećoj državi.

Također, pravilima fonda alokacija ulaganja među pojedinim sektorima ili državama nije bila unaprijed određena i mogla je varirati ovisno o tržišnim uvjetima. Prilikom ulaganja društvo za upravljanje predvidjelo je da će imovinu fonda ulagati u poslovne subjekte koji:

- promjenom poslovnog modela i/ili načina poslovanja kroz primjenu inovativnih tehnologija mogu ostvariti značajne iskorake u smislu rasta poslovanja i profitabilnosti

- razvijaju nove i jedinstvene proizvode i usluge koji nisu prisutni na tržištima na kojima poslovni subjekt posluje

76 Ponavljamo navod iz bilješke 50 da je lipnju 2020. izdano odobrenje Hanfe za osnivanje AIF-a poduzetničkog kapitala s privatnom ponudom Feelsgood investicijski fond s društvenim učinkom (venture capital fond), no on u rujnu 2020. još nije započeo s radom. 
- poslovne modele karakteriziraju lakoća uspostavljanja pružanja usluga ili prodaje proizvoda na nova tržišta uz nerazmjerno povećanje fiksnih troškova (scalability)

- razvijaju poslovne modele, tj. proizvode i usluge koje je moguće nuditi širokim demografskim i geografskim ciljanim skupinama klijenata

- potrebne su im nove menadžerske i stručne kompetencije kako bi model poslovanja prilagodili izazovima promjene tehnologije, preferencija i navika potrošača

- potreban im je kapital za razvoj i/ili optimizacija strukture financiranja.

Tablica 3.: Ulaganja fonda Inspirio Fusion (Inspire Fusion)

\begin{tabular}{|l|l|l|l|l|l|}
\hline \multicolumn{1}{|c|}{ INSPIRIO FUSION* } \\
\hline \multicolumn{1}{|c|}{ društvo } & \multicolumn{1}{|c|}{ sektor } & \multicolumn{1}{c|}{ opis } & tip ulaganja & \multicolumn{1}{c|}{$\begin{array}{c}\text { datum } \\
\text { ulaganja }\end{array}$} & $\begin{array}{c}\text { datum } \\
\text { izlaska }\end{array}$ \\
\hline $\begin{array}{l}\text { Fleet rent-a- } \\
\text { car d. o. o. } \\
\text { putem Inspire } \\
\text { usluge d. o. o.) }\end{array}$ & turizam & rent-a-car & $\begin{array}{l}65 \% \\
\text { vlasnički } \\
\text { kapital, } \\
35 \%\end{array}$ & $7 / 2016$ & $9 / 2017$ \\
& & & $\begin{array}{l}\text { akvizicijski } \\
\text { kredit }\end{array}$ & & \\
\hline Kompas d. d. & turizam & turizam & $\begin{array}{l}\text { vlasnički } \\
\text { kapital }\end{array}$ & $3 / 2017$ & $9 / 2017$ \\
\hline * fond je likvidiran u 10/2018, više ne postoji & \\
\hline
\end{tabular}

Izvor: Društvo za upravljanje Inspire Investments d. o. o.

Prema navodima društva inicijalno ulaganje jedinog ulagatelja u fond Inspire Fusion bilo je $\mathrm{u}$ iznosu od 6,5 milijuna kuna, s time da uplate $\mathrm{u}$ fond nisu bile uređene na načelu maksimalno preuzete obveze ulaganja, nego je ulagatelj svaki put kada bi fondu trebala sredstva za ulaganje ili plaćanje propisanih troškova vršio dodatne uplate (zbog čega je fond imao izraziti rizik likvidnosti).

Također, društvo je istaknulo da su oba ciljna društva bila obiteljska društva, ali je od prodavatelja (obitelj) VC fond stekao sve udjele u društvima, pa obitelj više nije bila uključena u poslovanje ciljnih društava. Zbog toga VC fond nije koristio ni nikakve zaštitne mehanizme, primjerice drag-along, tag-along, lock-up i sl. Strategija ulaganja za oba ciljna društva bila je Growth/Expansion - ulaganje u društva koja se bave pružanjem usluga u turizmu i vodeći su na tržištu u svom području te ostvarivanje rasta kroz sinergije i digitalizaciju usluge te promjenu koncepta poslovanja. Jedno ulaganje je napravljeno izravno, a drugo putem društva posebne namjene (SPV). Jedno je ulaganje ostvareno kroz vlasnički 
kapital, dok je kod drugoga korištena kombinacija vlasničkog kapitala (65 \%) i dužničkog financiranja (35\%). Što se tiče povrata, jedini ulagatelj u VC fond realizirao je isplatu svih udjela u VC fondu in specie (na njega su preneseni udjeli i dionice ciljnih društava te preostali novac s računa VC fonda nakon plaćanja svih troškova VC fonda) te je fond likvidiran. Prema javno dostupnim informacijama oba ulaganja VC fonda u konačnici su završila u stečaju.

Društvo za upravljanje je stava da Inspirio Fusion po:

- strukturi ulagatelja

- upravljačkoj povezanosti (jedini ulagatelj u fond bio je ujedno i imatelj kvalificiranog udjela (50 \%) u društvu za upravljanje i predsjednik uprave društva za upravljanje te je bio i u upravama ciljnih društava)

- odredbama pravila koja su primjerenija fondovima koji ulažu u likvidne financijske instrumente

više nalikuje društvu posebne namjene (SPV) tog jedinog ulagatelja, negoli je riječ o institucionaliziranom pristupu ulaganju kroz fondove. Društvo je u upitniku istaknulo kako fond Inspirio Fusion $\mathrm{u}$ analizi fondovske industrije $\mathrm{u}$ Hrvatskoj, pa tako i PE industrije, valja promatrati kao jednokratan i zaseban fenomen, a ne kao tipičan i ogledan primjer fondova svoje vrste, što u konačnici dokazuju i vrijeme njegova trajanja te završstak.

\subsection{Fondovi za gospodarsku suradnju (FGS)}

FGS-ovi su osnovani 2010. s ciljem prevladavanja teškoća u gospodarstvu, eliminiranja negativnih učinaka globalne krize na hrvatsko gospodarstvo, uz stvaranje uvjeta za dugoročno održivi gospodarski rast, kao jedna od mjera za gospodarski oporavak i razvitak kojima se potiče kreditna aktivnost. Njihova je svrha bila poticanje razvoja gospodarstva, očuvanje postojećih i stvaranje novih radnih mjesta, jačanje postojećih i pokretanje novih gospodarskih subjekata putem vlasničkog restrukturiranja ulaganjem dodatnog kapitala, i to uz suradnju hrvatske Vlade i zainteresiranih privatnih ulagatelja. Što se tiče "zakonodavnog" okvira FGS-ova, oni nisu bili posebno uređeni tada važećim ZIF-om, nego je hrvatska Vlada najprije posebnim odlukama, a zatim ministar zadužen za gospodarstvo i poduzetništvo pravilnicima, odredili prethodni postupak osnivanja FGS-ova, uvjete sudjelovanja hrvatske Vlade u FGS-ovima te uvjete i način njihova rada, prema kojima su specifičnosti FGS-ova sljedeće ${ }^{77}$ :

77 Odluka Vlade RH o namjeri sudjelovanja u osnivanju fondova za gospodarsku suradnju (Narodne novine, br. 8/2010), zatim Pravilnik o uvjetima i postupku sudje- 
- FGS se osniva kao otvoreni investicijski fond rizičnog kapitala s privatnom ponudom - dakle kao PE fond - na određeno vrijeme od deset godina uz mogućnost produljenja za maksimalni dodatni rok od dvije godine (što je u skladu s tada važećim ZIF-om).

- FGS će isključivo ulagati u društva koja imaju sjedište u Hrvatskoj i koja isključivo ili pretežito obavljaju svoju djelatnost na području Hrvatske.

- HBOR djeluje kao kvalificirani ulagatelj u svoje ime, a za račun hrvatske Vlade.

- Hrvatska Vlada ulaže ukupno do najviše 1 milijardu kuna.

- Veličina FGS-a je najmanje 150.000.000,00 kuna.

- Za osnivanje FGS-a privatni ulagatelji zajednički moraju preuzeti obvezu uplate od najmanje 75.000.000,00 kuna (prema ZIF-u to je najmanja veličina fonda).

- Maksimalna obveza uplate hrvatske Vlade prema jednom FGS-u može iznositi do 300.000.000,00 kuna, s time da udjel hrvatske Vlade ne može biti niži od $25 \%$ plus jedan udjel niti viši od 50 \% udjela.

- Jedno društvo za upravljanje može upravljati samo jednim FGS-om.

Navedenim je odlukama hrvatske Vlade i pravilnicima nadležnog ministarstva rad FGS-ova bio vrlo detaljno određen - od postupka osnivanja FGS-ova, njihova trajanja, područja ulaganja, depozitara, preko naknade za upravljanje i raspodjele dobiti (uključujući i internu stopu povrata te formulu za njezin izračun), obveze formiranja povjereničkog odbora, načina i rokova poziva na uplatu, pristupanja novih ulagatelja; do sukoba interesa društva za upravljanje, otkaza upravljanja FGS-om, pripajanja i spajanja FGS-ova te zaštite ugleda Hrvatske prilikom osnivanja FGS-ova. Napominjemo da su obveze povjereničkog odbora izričito propisane tim aktima, pa tako povjerenički odbor FGS-a ima najmanje sljedeća ovlaštenja: potvrđivati odluku o izboru revizora poslovanja fonda, usvajati financijske izvještaje o poslovanju fonda, donositi odluku o otkazu ugovora o upravljanju društvu za upravljanje, donositi odluku o likvidaciji fon-

lovanja Vlade Republike Hrvatske u osnivanju fondova za gospodarsku suradnju (Narodne novine, br. 21/2010, 42/2012), Odluka o imenovanju kvalificiranog ulagatelja za sudjelovanje u osnivanju fondova za gospodarsku suradnju (Narodne novine, br. 96/2010) te Pravilnik o sudjelovanju Vlade Republike Hrvatske u Fondovima za gospodarsku suradnju (Narodne novine, br. 42/2012, 138/2012, 18/2013 i 47/2013), dok su danas na snazi Pravilnik o sudjelovanju Vlade Republike Hrvatske u Fondovima za gospodarsku suradnju (Narodne novine, br. 47/2013) i Odluka o sudjelovanju u fondovima za gospodarsku suradnju (Narodne novine, br. 40/2013). Tako i Derenčinović Ruk, op. cit. u bilj. 11, str. 1665 i 1666. 
da, davati obvezujuće mišljenje na prijedlog odluke o ulaganju i raspolaganju imovinom, davati prethodnu suglasnost na izmjene i dopune akata fonda te promjene članova uprave društva za upravljanje, davati prethodnu suglasnost na pristup novih ulagatelja fondu.

Taj je projekt rezultirao osnivanjem triju novih društava za upravljanje fondovima rizičnog kapitala, a do 2011. osnovano je ukupno pet FGS-ova, koji su počeli s radom početkom $2011 .{ }^{78}$ Iz navedenoga više nego očito proizlazi da su FGS-ovi dali itekakav vjetar u leđa industriji PE fondova u Hrvatskoj, a pogledamo li današnju situaciju, razvidno je da bez FGS-ova u Hrvatskoj ne bi ni bilo PE fondova.

Što se tiče statističkih podataka, na 30. lipnja 2020. stanje je sljedeće ${ }^{79}$ :

- ukupna vrijednost neto imovine (NAV) FGS-ova iznosi 528.519.476,17 kn

- ukupna vrijednost neto imovine (NAV) AIF-ova iznosi 4.402.430.364,07 kn

- udio NAV-a FGS-ova u ukupnom NAV-u AIF-ova iznosi 12,01 \%.

Prosječna godišnja stopa rasta ukupnog NAV-a FGS-ova iznosila je ${ }^{80}$ :

- u razdoblju od 2011. do 2018. 46,43\%

- u razdoblju od 2011. do 2016. 72,5\%

- u razdoblju od 2016. do 2018. $-2,40 \%$

iz čega je vidljivo da su FGS-ovi do pete godine imali visoke stope rasta, a to je logično jer je riječ o utjecaju novih ulaganja.

Iz mjerodavne je regulative razvidno da FGS-ovi pripadaju kategoriji PE fondova, no uzevši u obzir snažan utjecaj ulagatelja na njihov rad kroz ovlaštenja povjereničkih odbora (davanje obvezujućeg mišljenja na prijedlog odluke o ulaganju i raspolaganju imovinom i dr.) i veliku prisutnost države, koja je najveći pojedinačni ulagatelj (50 \%), postavlja se pitanje je li takvo što u skladu s idejom PE fondova kao takvom. Pritom položaj države kao najvećeg ulagatelja nije problematičan sam po sebi, posebice kada država nastupa iure gestionis, a ne iure imperii, kao što je to slučaj kod brojnih Sovereign Wealth fondova. No PE fondovima nije svojstveno da ulagatelji imaju utjecaj na donošenje odluka o ulaganju i dezinvestiranju, a pogotovo ne da taj utjecaj bude presudan prilikom donošenja takvih odluka.

78 Do 2010. godine u Republici Hrvatskoj bila su osnovana dva društva za upravljanje fondovima rizičnog kapitala - Quaestus Private Equity d. o. o. i Nexus Private Equity Partneri d. o. o., a tada su osnovani Prosperus Invest d. o. o., Honestas Private Equity Partneri d. o. o. i Alternative Private Equity d. o. o.

79 Prema mjesečnim izvještajima dostupnima na internetskim stranicama Hanfe.

80 Prema podacima Hanfe i podacima prikupljenima od društava za upravljanje. 
U nastavku se navode konkretna ulaganja FGS-ova, prema podacima prikupljenima od društava koja njima upravljaju.

Tablica 4.: Ulaganja fonda Quaestus Private Equity Kapital IIO

\begin{tabular}{|l|l|l|l|l|l|}
\hline \multicolumn{7}{|c|}{ QUAESTUS PRIVATE EQUITY KAPITAL II } \\
\hline \multicolumn{1}{|c|}{ društvo } & \multicolumn{1}{|c|}{ sektor } & \multicolumn{1}{c|}{ opis } & $\begin{array}{c}\text { tip } \\
\text { ulaganja }\end{array}$ & $\begin{array}{c}\text { datum } \\
\text { ulaganja }\end{array}$ & $\begin{array}{c}\text { datum } \\
\text { izlaska }\end{array}$ \\
\hline Fragaria d. o. o. & $\begin{array}{l}\text { proizvodnja } \\
\text { hrane }\end{array}$ & $\begin{array}{l}\text { proizvodnja voća i } \\
\text { povrća }\end{array}$ & $\begin{array}{l}\text { vlasnički } \\
\text { kapital }\end{array}$ & $3 / 2012$ & \\
\hline $\begin{array}{l}\text { Tvornica tekstila } \\
\text { Trgovišće d. o. o. }\end{array}$ & $\begin{array}{l}\text { proizvodnja } \\
\text { tekstila }\end{array}$ & $\begin{array}{l}\text { proizvodnja stolnog i } \\
\text { posteljnog rublja }\end{array}$ & $\begin{array}{l}\text { vlasnički } \\
\text { kapital }\end{array}$ & $9 / 2012$ & \\
\hline $\begin{array}{l}\text { Drvna industrija } \\
\text { Spačva d. d. }\end{array}$ & $\begin{array}{l}\text { drvna } \\
\text { industrija }\end{array}$ & $\begin{array}{l}\text { proizvodnja drvnih } \\
\text { proizvoda }\end{array}$ & $\begin{array}{l}\text { vlasnički } \\
\text { kapital }\end{array}$ & $6 / 2013$ & \\
\hline
\end{tabular}

Izvor: Društvo za upravljanje Quaestus Private Equity d.o.o.

Tablica 5.: Ulaganja fonda Prosperus FGS

\begin{tabular}{|c|c|c|c|c|}
\hline \multicolumn{5}{|c|}{ PROSPERUS FGS } \\
\hline društvo & sektor & tip ulaganja & $\begin{array}{l}\text { datum } \\
\text { ulaganja }\end{array}$ & $\begin{array}{l}\text { datum } \\
\text { izlaska }\end{array}$ \\
\hline Vodoskok d. o. o. & $\begin{array}{l}\text { kemijska } \\
\text { industrija / } \\
\text { trgovina }\end{array}$ & $\begin{array}{l}\text { vlasnički kapital, } \\
\text { dokapitalizacija za širenje } \\
\text { poslovanja }\end{array}$ & $10 / 2012$ & \\
\hline Adriatic kampovi d. o. o. & turizam & $\begin{array}{l}\text { vlasnički kapital, } \\
\text { osnivanje društva koje će } \\
\text { uložiti u kupnju mobilnih } \\
\text { kućica te ih iznajmljivati }\end{array}$ & $2 / 2013$ & \\
\hline $\begin{array}{l}\text { Energija Gradec d. o. o. } \\
\text { (putem A.N.P. Energija } \\
\text { d. o. o.) }\end{array}$ & $\begin{array}{l}\text { energetika - } \\
\text { OIE bioplin }\end{array}$ & $\begin{array}{l}\text { vlasnički kapital, } \\
\text { dokapitalizacija za projektno } \\
\text { financiranje }\end{array}$ & $12 / 2013$ & \\
\hline $\begin{array}{l}\text { HTP Korčula d. d. (putem } \\
\text { Dalmacija Hoteli d. o. o.) }\end{array}$ & turizam & $\begin{array}{l}\text { vlasnički kapital, } \\
\text { dokapitalizacija }\end{array}$ & $2 / 2014$ & \\
\hline $\begin{array}{l}\text { HTP Orebic d. d. (putem } \\
\text { Dalmacija Hoteli d.o. o.) }\end{array}$ & turizam & $\begin{array}{l}\text { vlasnički kapital, } \\
\text { dokapitalizacija }\end{array}$ & $8 / 2014$ & \\
\hline $\begin{array}{l}\text { HRVATSKA POŠTANSKA } \\
\text { BANKA d. d. }\end{array}$ & financijski & $\begin{array}{l}\text { vlasnički kapital, } \\
\text { dokapitalizacija }\end{array}$ & $9 / 2015$ & \\
\hline Dalmacija Hoteli d. o. o. & turizam & $\begin{array}{l}\text { vlasnički kapital, } \\
\text { otkup udjela }\end{array}$ & $4 / 2016$ & \\
\hline Club Adriatic d. o. o. & turizam & $\begin{array}{l}\text { vlasnički kapital, } \\
\text { dokapitalizacija }\end{array}$ & $2 / 2020$ & \\
\hline
\end{tabular}

Izvor: Društvo za upravljanje Prosperus invest d. o. o. 
Tablica 6.: Ulaganja fonda Prosperus FGS II

\begin{tabular}{|l|l|l|l|l|}
\hline \multicolumn{5}{|c|}{$\begin{array}{l}\text { PROSPERUS FGS II } \\
\text { (NEXUS FGS II) }\end{array}$} \\
\hline \multicolumn{1}{|c|}{ društvo } & sektor & tip ulaganja & $\begin{array}{c}\text { datum } \\
\text { ulaganja }\end{array}$ & $\begin{array}{c}\text { datum } \\
\text { izlaska }\end{array}$ \\
\hline $\begin{array}{l}\text { Hoteli Plat d. d. } \\
\text { (putem KHA Četiri d. o. o.) }\end{array}$ & turizam & vlasnički kapital & $6 / 2015$ & \\
\hline $\begin{array}{l}\text { Centar banka u stečaju d. } d . \\
\text { (putem Alternative upravljanje d. o. o.) }\end{array}$ & financijski & vlasnički kapital & $6 / 2012$ & \\
\hline $\begin{array}{l}\text { J\&T Banka d. } \text { d. } \\
\text { (putem Alternative upravljanje d. o. o.) }\end{array}$ & financijski & vlasnički kapital & $1 / 2013$ & \\
\hline
\end{tabular}

Izvor: Društvo za upravljanje Prosperus invest d. o. o.

Tablica 7.: Ulaganja fonda Honestas FGS

\begin{tabular}{|l|l|c|c|c|}
\hline \multicolumn{4}{|c|}{ HONESTAS FGS } \\
\hline \multicolumn{1}{|c|}{ društvo } & sektor & tip ulaganja & $\begin{array}{c}\text { datum } \\
\text { ulaganja }\end{array}$ & $\begin{array}{c}\text { datum } \\
\text { izlaska }\end{array}$ \\
\hline $\begin{array}{l}\text { Conty plus d. o. o. } \\
\text { (putem Honestas Incrementa d. o. o.) }\end{array}$ & $\begin{array}{l}\text { drvna } \\
\text { industrija }\end{array}$ & vlasnički kapital & $9 / 2013$ & \\
\hline
\end{tabular}

Izvor: Društvo za upravljanje Fima invest d. o. o.

Tablica 8.: Ulaganja fonda Inspirio FGS (Nexus FGS)

\begin{tabular}{|c|c|c|c|c|}
\hline \multicolumn{5}{|c|}{$\begin{array}{l}\text { INSPIRIO FGS } \\
\text { (NEXUS FGS) }\end{array}$} \\
\hline društvo & sektor & tip ulaganja & $\begin{array}{l}\text { datum } \\
\text { ulaganja }\end{array}$ & $\begin{array}{l}\text { datum } \\
\text { izlaska }\end{array}$ \\
\hline $\begin{array}{l}\text { Dalekovod d. } d . \\
\text { (putem Konsolidator d. o. o.) }\end{array}$ & građevinski & vlasnički kapital & $2 / 2014$ & \\
\hline $\begin{array}{l}\text { Energija Gradec d. o. o. } \\
\text { (putem A.N.P. Energija d. o. o.) }\end{array}$ & $\begin{array}{l}\text { energetika - } \\
\text { OIE bioplin }\end{array}$ & vlasnički kapital & $12 / 2013$ & \\
\hline $\begin{array}{l}\text { Zagreb Montaža d. o. o. } \\
\text { (putem Inspirio ulaganje d. o. o.) }\end{array}$ & građevinski & vlasnički kapital & $7 / 2016$ & \\
\hline $\begin{array}{l}\text { Požgaj grupa d. o. o. } \\
\text { (putem Massive Holding d. o. o.) }\end{array}$ & \begin{tabular}{|l|} 
drvna \\
industrija
\end{tabular} & vlasnički kapital & $4 / 2012$ & $1 / 2019$ \\
\hline $\begin{array}{l}\text { Parketi Požgaj d. o. o. } \\
\text { (putem Požgaj Floring d. o. o.) }\end{array}$ & $\begin{array}{l}\text { drvna } \\
\text { industrija }\end{array}$ & vlasnički kapital & $4 / 2014$ & $1 / 2019$ \\
\hline $\begin{array}{l}\text { Podatkovni centar Križ d. o. o. } \\
\text { (putem Plavi podatak d. o. o.) }\end{array}$ & IT & vlasnički kapital & $12 / 2011$ & \\
\hline Boatbooker d. o. o. & IT & vlasnički kapital & $7 / 2012$ & $5 / 2020$ \\
\hline
\end{tabular}

Izvor: Društvo za upravljanje Inspire investments d. o. o. 
Kurzivom su u tablicama označena ciljna društva koja nisu privatna, nego su javna, tj. listana na Zagrebačkoj burzi d. d. - od šest ulaganja fonda Prosperus FGS polovica nisu privatna ulaganja, a dva od tri ulaganja fonda Prosperus FGS II bila su javna ulaganja u trenutku kada su izvršena ${ }^{81}$, i to su k tomu ulaganja $\mathrm{u}$ banke koje su pod posebnom regulacijom. Ulaganje u Centar banku d. $\mathrm{d}$. izvršeno je u lipnju 2012. godine, a ona je od rujna 2013. godine u stečaju.

Iz navedenih je podataka o ulaganjima FGS-ova vidljivo da su FGS-ovi orijentirani na različita sektorska područja (turizam, prehrambena industrija, drvna industrija, energetika), pa i financijski sektor koji je visoko reguliran, zbog čega inače nije preferirano područje ulaganja PE fondova. Također je vidljivo da se u pravilu ulaže u privatna društva, no ne uvijek jer je bilo ulaganja i u društva koja su listana na burzi, a neka još uvijek jesu.

FGS-ovi su u razdoblju od deset godina ostvarili 22 ulaganja putem pet fondova, s time da tu postoje značajne razlike među pojedinim fondovima - od Honestas FGS-a koji ima samo jedno ulaganje, preko Quaestus FGS i Prosperus FGS II koji imaju po tri ulaganja do Prosperus FGS i Inspirio FGS koji imaju šest i više ulaganja. Nadalje, vidljivo je da je više od polovice ulaganja (njih 13) ostvareno neizravno, tj. putem društava posebne namjene (SPV). Neki upravitelji smatraju da se korištenjem (nepotrebnih) društava posebne namjene (SPV) stvara složena struktura ulaganja koja povećava trošak upravljanja i otežava transparentno i izravno praćenje rezultata ulaganja i promjena u ciljanim društvima te omogućuje donošenje poslovnih i/ili ulagačkih odluka upitne pravne utemeljenosti i zaobilaženje propisane procedure.

Iz prikupljenih je podataka razvidno da je više od polovice ulaganja (njih 14) bilo u društva s ograničenom odgovornošću, dok ih je osam bilo u dionička društva, a pretežno se ulaže u mala i srednja poduzeća (SME), malo u velika, a minimalno u start-up (Boatbooker d. o. o. i Podatkovni centar Križ d. o. o.). Samo jedno društvo za upravljanje imovinu FGS-ova uopće nije ulagalo u obiteljska društva (Prosperus invest d. o. o.) i tu su iskustva društava različita, podjednako pozitivna i negativna, a ovise o industriji, složenosti poslova i situaciji u ciljnom društvu te osobnim obilježjima obitelji (partnera). S pozitivne strane društva ističu dobru komunikaciju i suradnju/kooperativnost, transparentan odnos, jednostavniji pristup, brže dogovaranje oko uvjeta/suradnje, fleksibilnost te bržu i efikasniju realizaciju ulaganja i projekta. S negativne strane društva ističu suradnju obilježenu netransparentnošću i sukobom interesa. Društva su putem upitnika kao glavno obilježje ulaganja u obiteljska društva istaknula

81 Centar banka d. d. je delistana (izvrštena) sa Zagrebačke burze u studenom 2017. godine, a J\&T Banka d. d. u ožujku 2014. godine. 
sinergijski potencijal izvora financiranja, profesionalnog upravljanja i kontrole od strane društva za upravljanje i ekspertnog znanja, iskustva te truda osnivača obiteljskog društva (partnera), čime se dobiva dobar potencijal za rast i napredak te se rješava ključni problem klasičnog obiteljskog SME društva. Međutim, ako se ne uspostavi jasan, sustavan i učinkovit sustav kontrole i korporativnog upravljanja, napominju da kod takvih ulaganja mogu biti itekako prisutni i izraženi poistovjećivanje obiteljskog društva (businessa) i osobe/obitelji osnivača uz tretman fonda i društva za upravljanje kao "stranog tijela", uspostavljanje paralelnog poslovanja od strane osnivača, nerazumijevanje biti poslovanja od strane društva za upravljanje i sl., što sve može rezultirati problemima za ciljno društvo, ali i gubitkom vrijednosti i za fond i za osnivača.

Prema iskustvima FGS-ova navedenima u upitniku osnivač obiteljskog društva kao partner FGS-u najčešće je nastavio samostalno voditi operativno poslovanje ciljnog društva jer ima dovoljno znanja, iskustva i kontakata za ostvarivanje zajedničkog cilja. Doduše, u situaciji izostanka sustavne kontrole od strane društva za upravljanje navedeno se pokazalo kao značajan čimbenik rizika s negativnim utjecajem na vrijednost ulaganja fonda. Naime, bilo je slučajeva kada se osnivač/direktor obiteljskog društva poistovjećivao s društvom te je dolazilo do transakcija s obilježjima sukoba interesa ili osnivač nije mogao sagledati širu sliku i kontekst poslovanja, odnosno pratiti principe korporativnog upravljanja koji su uobičajeni u slučajevima partnerstva s institucionalnim ulagateljima kao što je PE fond. Nasuprot tomu, postojala su i obiteljska društva u kojima je ugovoreni oblik suradnje i korporativne kulture zaživio i gdje je osnivač kao ekspert na svojem području pridonio rezultatu rada ciljnog društva i zajedničkom povećanju vrijednosti zalaganjem i trudom koji se ne bi mogao očekivati od profesionalnog menadžera koji nije i imatelj udjela u društvu.

Što se tiče preferiranih strategija ulaganja FGS-ova, one variraju, no društva navode da preteže strategija Growth/Expansion, zatim Distressed/Turnaround i Restructuring te start-up, a samo je jedno ulaganje ostvareno putem Mezzanine strategije, i to ne u potpunosti. Gotovo sva ulaganja realizirana su ulaganjem vlasničkog kapitala, samo u jednom slučaju korištena je kombinacija vlasničkog kapitala (37 \%) i dužničkog financiranja (konvertibilni mezzanine zajam - 63 \%), a u tijeku je konverzija toga zajma u rezerve kapitala (equity poziciju).

Zanimljivo je da hrvatska društva za upravljanje navode kako due diligence proces kod FGS-ova ne traje dugo - u prosjeku jedan do tri mjeseca (ovisno o veličini ciljnog društva), rijetko tri do šest mjeseci, a društva za upravljanje pregledaju/razmatraju od 50 do 500 projekata / potencijalnih ulaganja prije no što se odluče za konkretno ulaganje u ciljno društvo. FGS-ovi kontrolu nad ciljnim društvom ostvaruju kombinacijom različitih mehanizama - ponajprije 
redovitim sastancima s ciljnim društvom, zatim putem nadzornog odbora i uprave (ponekad i imenovanjem prokurista u ciljnom društvu), a ugovaraju se i zaštitni mehanizmi kroz društveni ili dioničarski ugovor. U ugovorima o ulaganju u ciljno društvo ${ }^{82}$ društva navode da se obuhvaćaju različita područja - način izračuna cijene, (pred)uvjeti zaključenja ugovora, odredbe potrebne za prijenos udjela, korištenje sredstava od dokapitalizacije, korporativno upravljanje (uprava i nadzorni odbor), prava raspolaganja udjelima/dionicama ciljnog društva, prava i zaštitni mehanizmi za fond, jamstva imatelja udjela, ugovorne kazne, povjerljivost i zabrana tržišne utakmice te način rješavanja sporova.

Što se tiče izlaska iz ciljnog društva, hrvatski FGS-ovi preferiraju prodaju strateškom partneru ili partneru u projektu. U Hrvatskoj do sada nisu zabilježeni slučajevi da se iz PE ulaganja izašlo putem inicijalne ili sekundarne javne ponude (IPO, SPO). Društva su u upitniku navela da je bilo i slučajeva otpisa pojedinih ulaganja (write-off). Kod izlaska iz ciljnog društva predviđaju se razni zaštitni mehanizmi i prava - pravo prvenstva (pri preuzimanju novih poslovnih udjela/dionica), pravo prvokupa, drag-along, tag-along i lock-up, a u nekim slučajevima i vinkulacija (zabrana raspolaganja manjinskim udjelima bez suglasnosti FGS-a), call opcija za preuzimanje udjela manjinskog partnera te založno pravo kod konvertibilnog zajma.

I u konačnici - povrat, tj. je li ostvarena interna stopa povrata u ulaganjima i u koliko slučajeva? To je pitanje u ovome trenutku gotovo bespredmetno jer je vidljivo da za većinu ulaganja FGS-ova još nije ostvaren izlaz, tj. dezinvestiranje, premda bi FGS-ovi već trebali biti u poodmakloj fazi dezinvestiranja jer su "navršili” deset godina života. Zbog toga je moguće da će se putem povjereničkih odbora zatražiti produljenje trajanja FGS-ova. No, prema podacima dobivenima od društava za upravljanje, u do sada ostvarenim izlazima nije realiziran povrat te je pitanje u kojim će slučajevima u budućnosti i biti realiziran povrat.

Iz svega navedenoga vidimo da PE, premda je donekle prisutan u Hrvatskoj, još ne igra gotovo nikakvu, a kamoli značajnu ulogu kao u nekim razvijenim zemljama. Neki od razloga su sigurno još uvijek plitko, slabo likvidno i nerazvijeno tržište kapitala, ali ni sami poduzetnici nisu dobro upoznati s cjelokupnim investicijskim procesom PE fondova i nisu investicijski spremni za privlačenje takvog oblika kapitala; također, poduzetnici nisu sigurni koje su prednosti, a koji nedostaci ovog oblika kapitala te ne znaju što nudi, a što traži ovaj oblik kapitala, niti su spremni na odricanje od "vlasništva". 83

82 To često budu ugovori o prodaji i prijenosu udjela/dionica.

83 Tako Šimić, op. cit. u bilj. 1, str. 280 i 281. 
Za razliku od toga, prema podacima Invest Europe za 2018. godinu ${ }^{84}$ u Europi (dakle, ne u Europskoj uniji) bilo je 688 milijardi eura imovine pod upravljanjem PE fondova, kojima upravlja više od 1400 društava za upravljanje PE fondovima. Samo u 2018. godini prikupljeno je više od 97,3 milijardi eura (u 2017. godini prikupljeno je 96,6 milijardi eura), a od toga je putem Buyout strategija prikupljeno 66,5 milijardi eura, putem VC strategija 11,4 milijarde eura (najviše do sada), a putem Growth strategija 7,8 milijardi eura. Ukupan iznos uložen u 7800 europskih ciljnih društava je 80,6 milijardi eura, a dezinvestirano je iz 3750 europskih ciljnih društava. Nadalje, prema podacima Invest Europe za 2018. godinu za područje središnje i istočne Europe (CEE) ${ }^{85}$, koje obuhvaća i Hrvatsku, prikupljeno je 1,82 milijardi eura, što je najviše u posljednjih deset godina za navedeno područje.

Što se tiče Hrvatske, kada se gleda godišnja vrijednost ulaganja u Hrvatsku od strane PE fondova iz Europe, ona iznosi 13 milijuna eura za 2015. godinu za četiri ciljna društva, 41 milijun eura za 2016. godinu za šest ciljnih društava, samo tri milijuna eura za 2017. godinu za tri ciljna društva i 77 milijuna eura za 2018. godinu za osam ciljnih društava (riječ je o ulaganjima u Hrvatsku, tj. hrvatska ciljna društva). U 2018. godini u Hrvatsku je putem PE ulaganja uloženo 0,149 \% BDP-a, a najviše se ulaže u start-up i growth etapi razvoja ciljnog društva. Što se tiče dezinvestiranja iz hrvatskih ciljnih društava, ona nisu ostvarena u 2018. i 2017. godini, dok ih je u 2016. godini bilo dva u vrijednosti od 20 milijuna eura, a u 2015. godini jedno u vrijednosti od 13 milijuna eura.

\section{ZAKLJUČAK}

Ovim se radom nastojao približiti jedan mali, ali značajan segment tržišta kapitala koji nudi alternativu klasičnom bankarskom financiranju - PE fondovi. Naime, različite vrste investicijskih fondova ulažu u različitu imovinu te su prema svojim karakteristikama, strukturi ulaganja i različitim razinama rizika dostupni s jedne strane ulagateljima, a s druge onima u koje ulažu imovinu fonda. PE fondovi su specifični jer ulažu u privatna društva dionice kojih nisu uvrštene na uređenom tržištu ili burzi radi trgovanja, a čine to putem transakcija koje se uvijek pregovaraju i dogovaraju privatno, nikada javno, i upravo je to ključno za uspjeh samoga ulaganja. Ulaganja PE fondova realiziraju se putem različitih oblika equityja ciljnog društva - od redovnih i povlaštenih dionica

\footnotetext{
84 Invest Europe, European Private Equity Activity 2018, Statistics on Fundraising, Investments and Disinvestments.

85 Invest Europe, Central and Eastern Europe Private Equity Statistics 2018. (7/2019).
} 
kao najjednostavnijih, preko složenijih instrumenata koji su "nalik vlasničkim instrumentima”, a obuhvaćaju kombinaciju equityja i duga; do vrlo složenih i za hrvatsko tržište umnogome nepoznatih izvedenica.

Jedna od karakteristika PE fondova, po kojima su poznati, njihova je rizičnost, koja proizlazi iz njihovih ulaganja i načina rada. Brojna PE ulaganja ne uspiju iz raznih razloga, pa je rizik uspješnosti ulaganja jedan od primarnih rizika za ulagatelje, a proizlazi iz inicijalne procjene potencijalnog ulaganja te kasnijeg upravljanja ulaganjem. Osim toga, riječ je i o vrlo nelikvidnim ulaganjima jer ciljna društva nisu listana na uređenom tržištu.

U svijetu u različitim jurisdikcijama postoje različite strukture PE fondova, ponajprije zbog poreznih razloga jer je ključno oformiti strukturu PE fonda koja će onemogućiti oporezivanje na razini fonda, dok je oporezivanje ulagatelja u fond moguće. To se u svijetu ostvaruje kroz formu (private) limited partnershipa koji nema pravnu osobnost, a sačinjavaju ga general partner, koji neograničeno odgovara za obveze fonda, i limited partner, koji odgovara ograničeno. U tom dijelu hrvatsko zakonodavstvo i praksa značajno odstupaju jer opisana struktura najviše odgovara komanditnom društvu, no u Hrvatskoj nije dopušteno osnovati PE fond kao pravnu osobu u tom obliku, nego samo kao d. d. ili d. o. o. Te dopuštene forme ni približno ne odgovaraju gotovo nijednoj vrsti AIF-a i povezane su s nerazmjernim troškovima (posebice kada je riječ o d. d.-u), pa su gotovo svi hrvatski PE fondovi otvoreni fondovi bez pravne osobnosti. Stoga bi se što prije trebale usvojiti odgovarajuće promjene mjerodavne regulative koja bi dopustila osnivanje AIF-ova s pravnom osobnošću i u formi komanditnog društva. Osim toga, a budući da regulativa to dopušta, bilo bi bolje da se PE fondovi u Hrvatskoj osnivaju kao zatvoreni AIF-ovi, a ne otvoreni. Smatramo da bi se takvim zakonodavnim i praktičnim promjenama mogao ostvariti puni potencijal PE fondova.

Hrvatsko PE iskustvo nije bogato i svodi se na poslovanje FGS-ova, koji su bez sumnje bili korisna inicijativa, no za sada još ne možemo govoriti o rezultatima njihova rada jer ostaje otvoreno pitanje hoće li prestati s radom u 2021. ili će se njihov životni vijek produljiti do 2023., pa tek ostaje vidjeti kako će se točno i pod kojim uvjetima dezinvestirati te hoće li ostvariti ikakav povrat na ulaganja.

\section{LITERATURA}

Baks, K. P., Alignment of Interest in the Private Equity Industry, Emory Center for Alternative Investments, 7/2010, str. 1 - 15.

Banal-Estanol, A.; Ippolito, F., Contractual Terms and Conditions in Private Equity Partnership Agreements, SSRN Electronic Journal, 11/2012, str. 1 - 42; DOI: 10.2139/ssrn.1022023 
Chemmanur, T. J.; Nandy, D.; Yan, A.; Jiao, J., A theory of mandatory convertibles, Journal of Banking and Finance, vol. 42, 2014., str. 352 - 370.

Chemmanur, T. J.; Nandy, D.; Yan, A., Why Issue Mandatory Convertibles? Theory and Empirical Evidence, 2004., str. 1 - 40.

Chertok, S.; Braendel, A. D., Closed-end Private Equity Funds: A Detailed Overview of Fund Business Terms Part 1 and 2, Legal Studies Research Paper, No. 35 2013 i 36-2013., str. 33 - 54.

Čulinović-Herc, E.; Braut Filipović, M.; Audić Vuletić, S., Novo pravno uređenje private equity $i$ venture capital fondova i otvorena pitanja, Zbornik Pravnog fakulteta Sveučilišta u Rijeci, vol. 38, br. 1, 2017., str. 51 - 92; DOI: 10.30925/ zpfsr.38.1.3

Davidoff, S. M., The Failure of Private Equity, Southern California Law Review, vol. 82, 2009., str. $481-545$.

Derenčinović Ruk, M., Restrukturiranje društava u poteškoćama $i$ tržište kapitala - vrste i upravljanje sukobom interesa, Zbornik Pravnog fakulteta Sveučilišta u Rijeci, vol. 39, br. 4, 2018., str. 1655 - 1680; DOI: 10.30925/zpfsr.39.4.8

Derenčinović Ruk, M., Odnos povjerenja u hrvatskom pravu, Hrvatska pravna revija, br. 10, 2016.

Harris, L., A critical theory of private equity, Delaware Journal of Corporate Law, vol. 35, br. 1, 2010., str. 260 - 293.

Payne, J., Private Equity and its Regulation in Europe, Oxford Legal Research Paper Studies, Paper No. 40/2011, 7/2011, str. 1 - 24.

Šimić, M., Atraktivnost hrvatske u privlačenju ulagača rizičnog kapitala, Ekonomska misao i praksa, br. 1., 2015., str. $267-294$.

Van Dam, M.; Mullmaier, J., Impact of AIFMD on the Private Equity Industry, u: Zetzche, D. A. (ur.), The Alternative Investment Fund Managers Directive, Second Edition, Kluwer Law International, 2015., str. 695 - 706.

Wymeersch, E., The regulation of private equity, hedge funds and state funds, Financial Law Institute, Working Paper Series WP 2010-06.

\section{IZVORI}

\section{a) dokumenti}

Comparative Study of Equity Investing in Development Finance Institutions, Office of Evaluation and Oversight (OVE) March 2017.

Debevoise \& Plimpton, Private Equity Funds, Key Business, Legal and Tax Issues, 2015. 
European Commission Internal Market and Services DG, Report of the Alternative Investment Expert Group Developing European Private Equity, July 2006.

Invest Europe, Central and Eastern Europe Private Equity Statistics 2018. (7/2019). Invest Europe, European Private Equity Activity 2018, Statistics on Fundraising, Investments and Disinvestments

Pantheon, Understanding private equity and private equity funds

\section{b) vrela $s$ interneta}

https://www.investopedia.com/terms/p/privateequity.asp (19. travnja 2020.)

https:/www.blackrock.com/us/individual/education/what-are-alternative-investments/private-equity-investing (19. travnja 2020.)

https://www.institutionalinvestor.com/article/bl5jkqt382wm4r/why-critics-areslamming-an-increasingly-popular-private-equity-format (19. travnja 2020.) https://www.researchgate.net/publication/325881915_Cheap_Debt_or_Delayed_Equity_The_Motives_for_the_Use_of_Convertible_Bonds_By_Companies_in_Poland (19. travnja 2020.)

https://www.lawinsider.com/dictionary/synthetic-equity (19. travnja 2020.)

https://www.businessinsider.com/synthetic-equity-ubs-2011-9 (19. travnja 2020.) http://cdn.sqlogin.com/prod/sq_uploads/boldvalue.com/documents/articles-for-inspiration/Synthetic-Equity-for-High-Performance-2019.pdf (19. travnja 2020.)

https://www.investopedia.com/terms/p/phantomstock.asp (19. travnja 2020.)

https://www.thebalance.com/how-phantom-stock-works-4159362 (19. travnja 2020.)

https://www.investopedia.com/terms/f/fullydilutedshares.asp (19. travnja 2020.) https://www.lawinsider.com/dictionary/fully-diluted-equity (19. travnja 2020.) https://www.lathamdrive.com/resources/insights/issued-and-outstanding-shares-versus-fully-diluted-shares (19. travnja 2020.)

https://medium.com/@adjblog/understand-how-to-read-fully-diluted-sharesand-total-outstanding-stock-in-a-cap-table-44e5a589322 (19. travnja 2020.) https://ilpa.org/wp-content/uploads/2019/06/ILPA-Principles-3.0_2019.pdf (19. travnja 2020.)

https://tockanai.hr/poduzetnik/financiranje/invera-private-equity-fond-24837/ (19. travnja 2020.)

https://www.tportal.hr/biznis/clanak/ebrd-ulaze-10-milijuna-eura-u-private-equity-fond-20190709 (19. travnja 2020.) 
https://www.ebrd.com/work-with-us/projects/psd/invera-private-equity-fund. html (19. travnja 2020.)

https://www.opalesque.com/677547/Private_equity_assets_under_management_crosses754.html (19. travnja 2020.)

https://www.quaestus.hr/o-nama/rizicni-kapital/investicijska-strategija/ (26. travnja 2020.)

https://www.poslovni.hr/trzista/prvi-vc-fond-razvijen-u-hrvatskoj-krece-u-sijecnju-356159 (26. travnja 2020.)

https://slobodnadalmacija.hr/vijesti/biznis/feelsgood-je-prvi-domaci-fond-za-ulaganja-s-drustvenim-utjecajem-milijune-ulazemo-u-tvrtke-zbog-kojih-ce-djeca-zavoljeti-znanost-63374l (26. travnja 2020.)

https://tockanai.hr/poduzetnik/financiranje/invera-private-equity-fond-24837/ (26. travnja 2020.)

https://www.tportal.hr/biznis/clanak/ebrd-ulaze-10-milijuna-eura-u-private-equity-fond-20190709 (26. travnja 2020.)

https://www.ebrd.com/work-with-us/projects/psd/invera-private-equity-fund. html (26. travnja 2020.)

\section{c) pravni akti}

Zakon o investicijskim fondovima (Narodne novine, br. 150/05)

Zakon o alternativnim investicijskim fondovima (Narodne novine, br. 16/13 i 143/14)

Zakon o alternativnim investicijskim fondovima (Narodne novine, br. 21/18 i 126/19)

Zakon o trgovačkim društvima (Narodne novine, br. 111/93, 34/99, 121/99, 52/00, 118/03, 107/07, 146/08, 137/09, 125/11, 152/11, 111/12, 68/13 i 110/15)

Pravilnik o vrstama alternativnih investicijskih fondova (Narodne novine, br. 28/19 i 15/20)

Pravilnik o vrstama alternativnih investicijskih fondova (Narodne novine, br. 105/13 i 28/15)

Delegirana uredba Komisije (EU) br. 231/2013 od 19. prosinca 2012. o dopuni Direktive 2011/61/EU Europskog parlamenta i Vijeća u odnosu na izuzeća, opće uvjete poslovanja, depozitare, financijsku polugu, transparentnost i nadzor

Odluka o namjeri sudjelovanja u osnivanju fondova za gospodarsku suradnju (Narodne novine, br. 8/10)

Odluka o imenovanju kvalificiranog ulagatelja za sudjelovanje u osnivanju fondova za gospodarsku suradnju (Narodne novine, br. 96/10) 
Odluka o sudjelovanju u fondovima za gospodarsku suradnju (Narodne novine, br. 40/13)

Pravilnik o uvjetima i postupku sudjelovanja Vlade Republike Hrvatske u osnivanju fondova za gospodarsku suradnju (Narodne novine, br. 21/10 i 42/12)

Pravilnik o sudjelovanju Vlade Republike Hrvatske u Fondovima za gospodarsku suradnju (Narodne novine, br. 42/12, 138/12, 18/13 i 47/13)

Pravilnik o sudjelovanju Vlade Republike Hrvatske u Fondovima za gospodarsku suradnju (Narodne novine, br. 47/13) 


\section{Summary}

\section{Morana Derenčinović Ruk ${ }^{*}$}

\section{PRIVATE EQUITY FUNDS AND CROATIAN EXPERIENCE}

Private equity funds are important players in the capital market, investing billions of dollars and euros in portfolio companies every year worldwide and in Europe, thus improving their business and development at almost all stages of their life cycle. Although Croatia lags far behind in this respect - both in terms of foreign private equity funds investing in Croatian companies and in terms of developing the private equity industry in Croatia - we believe it is important to analyze private equity funds and their characteristics in order to gain a full understanding of them. Therefore, this paper will try to define private equity funds and private equity and their interconnection, and explain the various forms and types of equity issued in private equity investments. Furthermore, the paper outlines the basic characteristics of private equity funds, which are crucial for understanding the way they operate, the relationship with the portfolio company and investors. Private equity funds have a specific lifespan and term, and bear significant risks (greater than those of the "infamous" hedge funds). They are meant for professional investors whose approach in portfolio companies is "hands on". The paper also presents the most common structures of private equity funds, which differ significantly from those in Croatia, whose legislative framework unfortunately still places strong legal obstacles for the efficient and effective functioning of private equity funds. Finally, the paper presents the Croatian experience with private equity funds, with a description of the first private equity funds in Croatia and a special reference to economic cooperation funds, as a special feature of the Croatian capital market and private equity industry.

Keywords: private equity, alternative investment fund, economic cooperation funds, strategy

* Morana Derenčinović Ruk, Ph. D., Croatian Financial Services Supervisory Agency, Franje Račkoga 6, 10000 Zagreb, Croatia; mderencinovic@gmail.com,morana.derencinovic@hanfa.hr;

ORCID ID: orcid.org/0000-0002-6624-7896 